\title{
The Anthropology of Northwest Coast Oral Traditions
}

\author{
Brian Thom
}

\begin{abstract}
This paper is a critical history of anthropological research on the oral traditions of the cultures of the Northwest Coast of North America, where much influential work has been done using the vast text collections compiled by Boas and his collaborators. The paper reviews the development and legacy of the Boas collection and analyses of Northwest Coast texts. In addition the paper analyzes responses to this body of work by functionalists who have looked to Northwest Coast myth as a way of understanding property, and responses by structuralists who have sought ways of understanding underlying meanings in these traditions. Recent contributions have focused on a more literary analysis of oral traditions. Finally, suggestions are made as to some future avenues for future study of Northwest Coast oral traditions.
\end{abstract}

\section{Oral Traditions and Theoretical Approaches to Discourse}

For Anthropologists working in Native North America, the verbal, textual, performed, and artisatic discourses of the people that we study are the E central, if not the defining elements of how we $\$$ come to understand and describe other cultural \& systems. Anthropologists studying the cultures of Native North America have built an academic tradition by discussing their positions in these discourses and their continuing efforts to reposition and recontextualize themselves within them. Anthropologists have written, presented, testified, exhibited, and sometimes even acted out our ever-changing understandings of the discourses of the communities in which we work. The message we have tried to express has changed since Boas collected his first Native text, but the objects of our study, Native discourses on myth, legend, folklore, history, life history, and (auto-) biography, have remained a core focus for the production of meaning and understanding within our discipline.
This paper presents a critical history of anthropological writing about Native Northwest Coast ${ }^{1}$ oral traditions. Emphases and perspectives have changed throughout this rich history of study, ranging from Boas' expansive collection of texts to studies of the social function of oral traditions, to interest in symbol, structure and meaning of myths, to a more literary interest in the ethnography of speaking. Though not reviewed here in detail, oral traditions of Northwest Coast Native people have also been at the core of the current political and legal debates in Canada over aboriginal title and rights (Thom 2001).

The current theoretical position of many contemporary Americanist anthropologists is relevant to the study of Northwest Coast oral traditions. This position holds that culture is a system of symbols, and that underlying culture is a complex interplay of basically inseparable elements of language, thought, and reality (Valentine and Darnell 1999:6). By focusing on one kind of Native discourse-oral traditions-a rich set of texts is generated, which can be studied to learn some-

Brian Thom, Department of Anthropology, McGill University Montreal, Quebec H3A 2T7, Canada 
Table 1. Synonymy for Northwest Coast Cultural and Linguistic Group Names.

This list of names represents the widely practised (Suttles 1990) English spellings of the Northwest Coast cultural, regional and linguistic group names, with their equivalents from the literature cited here. Cultural or regional groups not mentioned are in square brackets [ ], and often on one line. Regional groups are not elaborated for those cultural groups which are only mentioned generally in the text. As there are so many local groups, those not mentioned in the text are not elaborated on here.

\begin{tabular}{|c|c|c|c|c|}
\hline CULTURAL GROUPS & Languages & Regional Groups & Local Groups & Region \\
\hline EYAK & & & & \multirow{4}{*}{$\begin{array}{c}\text { Northern } \\
\text { NWC }\end{array}$} \\
\hline TLINGIT & & & & \\
\hline HAIDA & & $\begin{array}{l}\text { Kaigani, } \\
\text { Massett, } \\
\text { Skidegate }\end{array}$ & & \\
\hline TSIMSHIAN & & $\begin{array}{l}\text { Tsimshian, } \\
\text { Nisga'a, } \\
\text { Gitksan, }\end{array}$ & $\begin{array}{l}\text { Gitanyow } \\
\text { (=Kitwancool) }\end{array}$ & \\
\hline
\end{tabular}

\begin{tabular}{l}
$\begin{array}{l}\text { KWAKIUTL }(=\text { KWAGUL, Kwak'wala } \\
=\text { KWAKWAKA'WAKW) }\end{array}$ \\
\hline [HAISLA, HEILTSUK, \\
OOWEKYALA]
\end{tabular}

NOOTKA

(=NUU-CHAH-NULTH)

BELLA COOLA

COAST SALISH

\begin{tabular}{|c|c|c|}
\hline & Island Comox (= Çatloltq), & \\
\hline & Pentlatch, & \\
\hline & Klahoose, & \\
\hline & Sliammon, & \\
\hline & [Homalco, Sechelt], & \\
\hline & Squamish, & \\
\hline Halq'eméylem & Island Halkomelem, & \\
\hline$(=$ Halkomelem $)$ & $\begin{array}{l}\text { Upriver Halkomelem } \\
\text { (=Stó:1ô) }\end{array}$ & Katzie, \\
\hline Straits Salish & Straits Salish (=Lku'ñgEn), & Saanich, \\
\hline & & Klallam, \\
\hline Lushootseed & Lushootseed, & Upper Skagit \\
\hline & Quinault, & \\
\hline & Twana, & \\
\hline & [Chehalis, Cowlitz] & \\
\hline
\end{tabular}

QUILEUTE

[CHEMAKUM]

CHINOOK

[CATHLAMET] 
thing of that culture's communicative systems and norms, and the way these norms are put into action through the practice of telling the stories. It is in this interplay between structured cultural/linguistic practice and the agency of individual storytellers where culturally situated meanings lie. To be able to navigate this conceptual territory between the structure of oral traditions and the agency of narrating them, one needs to explore the connections between form and meaning. Such an examination grapples with the interplay of literature, linguistics, and ethnography in the realms of cosmology, marriage, descent, succession, political inequality, and the nature of human relations to non-humans. By laying out these communicative practices, we can begin to see how individuals use them to make meaning in their own social context.

It is clear, however, that this kind of aca$\nexists$ demic discourse is not centered on the object of Native discourse (Hill 1999:181). Native oral tradiôtions on the Northwest Coast are often concerned . with negotiating power relations between individکุ่uals in that society. In being told and retold, they -are often concerned with very particular and highly local social processes and situations. Each narrative in Native discourse is "connected to ธี every other [narrative] and to a highly contextual$\vec{\Delta}$ ized discourse that assumes familiarity with biogכ. raphy and shared experience" (Ridington ف1999:22). Thus, Native discourse is "in conversaEt tion and dialogue" (Ridington 1999:19; see also Sarris 1993:5), and it is a dialogue in which ano thropologists, by and large, are not engaged. They become particularly removed from this dialogue when stories are abstracted from their social setting and presented as "the mythology of such-andsuch a tribe." Readers must keep in mind that the anthropological discourse is very seldom about the real object of the Native discourse on this fine level, but tends to operate at a level of abstraction, trying to narrow the gap in meaning between the culture of the discourse makers and that of their non-local (often unintended) audience.

The objects of anthropological study-our implicit or explicit theoretical goals-are seldom those of the narrators of the oral traditions from which the anthropological goals are met. The gap between the meanings of oral traditions told by Native narrators and those meanings ascribed by anthropologists becomes greater as the goals of anthropological theory move further away from understanding local culturally and historically situated contexts. Of course, particular studies of the local (at which Boas excelled) are not the only kinds of questions which can be asked of oral traditions. Still, when researchers ask questions driven by their theoretical interests, we must recognize such questions and answers are a different kind of social act than that involved in the original telling of the oral traditions themselves. All social acts are imbued with relations of power and the accompanying potential for dominance, hegemony, and resistance. Thus, even the seemingly innocuous categorization of Native oral traditions as myth or legend, house story, or tale can take on a highly potent social life in arenas where myth is transformed into common law and house stories become legal codes.

\section{Franz Boas' Native Texts-Oral Traditions as History and Culture}

Any analysis of the anthropological discourse on Northwest Coast oral traditions must consider the foundational work of Franz Boas who personally did more towards the collection and publication of these as texts than any other scholar (Jacobs 1959a). For Boas, his colleagues, and students, Native texts were first seen as important kinds of data for obtaining information about the history and distribution of culture. In his early work for the British Association for the Advancement of Science and the Jesup North Pacific Expedition, Boas primarily studied the distribution of elements in oral traditions in order to show relative historical movements of cultural groups-resolving historical questions about the prehistory of Native America, and the contacts between the Northwest Coast of North America and the northeastern regions of Asia (Boas 1903; Cole 2001). In his later work at Columbia University, Boas struggled with the problem of how cultural outsiders-with all their biases and preconceptions-could gain insight into the ways that Native people understood their world and the ways in which they ascribed meaning to the stories (Boas 1935). Documenting oral traditions provided a means to discover what was important to Native people, in their own words, untroubled by the pre-selected responses of the question-answer methodology of participant observation. The legacy of this work holds major importance for the development of anthropology, in general, and to the current shape of anthropological studies on the Northwest Coast.

During his career, Boas made collections of texts in a great many of the languages spoken on the Northwest Coast. ${ }^{2}$ Boas had an acute ear for phonetic dictation and was able to record (and 
publish) a great deal of material in the original language. Boas was forced to work in Chinook Jargon and English when dealing with some of the languages with which he was completely unfamiliar, or when he did not have much time to take dictations. In these cases, the published versions are almost always in English only.

Of greater importance in terms of sheer volume, however, are the two major collections of Native language texts that came out of Boas' first-hand work with collaborators living in the communities they were documenting. The most well known are the Kwakiutl texts, which George Hunt produced for Boas (Boas 1910, 1935; Boas and Hunt 1905, 1906). Boas also had a long, active correspondence with Henry Tate, which ultimately produced a series of Tsimshian texts (Boas 191@ 1916). Given that these are among Boas’ most thorough and well-known works, they will be the focus of this paper.

ôWhile Boas collected several hundred pages' worth of Kwak'wala texts himself (i.e., Boas 1918::1-243), most of the Kwakiutl texts were takêํ down phonetically by Hunt in the Kwạk 'wala, a translation provided, and then sent

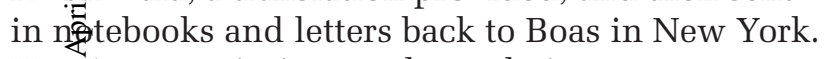
Hung's transcriptions and translations were reviewed and corrected by Boas from his office. The witlo Native language version, some with a mor heme-by-morpheme translation, and most witt a running summary English translation. This sep孚ation of the texts from their contexts makes therd daunting objects to approach. The highly techical phonetic transcription and often awkwarg, literal translation make the texts seem like oddities to the student with little prior knowledge of Kwakiutl culture. Boas was criticized for this at the time by Sapir, who argued that he had not provided adequate annotations of these texts, which could help "the student of Kwakiutl mythology and culture towards the understanding of the tales" (Sapir 1912:197).

For Tate's Tsimshian texts, the path to publication took a more complicated route. Tate took down versions of the stories he knew or heard in English, and then proceeded to translate them into Tsimshian, which he sent to Boas (Barbeau 1917:562; Maud 1989:158). Boas was never satisfied with Tate's transcriptions of Tsimshian, so he had Archie Dundas, a Tsimshian-speaker who was studying on the East coast, read Tate's Tsimshian out loud, which Boas then re-transcribed. Not wanting to be biased by Tate's English, Boas drew on his own limited knowledge of Tsimshian to retranslate the Dundas transcriptions in the same fashion he had done with the Kwakiutl material. The final results were published in the style of Hunt's Kwakiutl work. The Tsimshian texts are subject to the same critique as the Kwakiutl material, though the long path of translation makes it more difficult to be satisfied with this material as representing the narratives of a living community. While Maud has critiqued the Boas-Tate collaboration as something of a scientific charade (Maud $2000)^{3}$, these texts represent more the work of a unique anthropological collaboration. Boas' method of publishing the Kwakiutl and Tsimshian texts is important to review because the texts are the basis of several subsequent generations of anthropological study of these communities. Anthropologists frequently use the texts as if they are authoritative, original sources that stand for nineteenth century Northwest Coast cultures.

Apart from presenting the texts themselves, Boas' analyses are limited. Boas was loath to see these oral traditions as forming a cultural system, unlike his colleagues overseas, who were influenced by Durkheim and Malinowski, or the older Americanist school of Holmes and Dorsey from the Bureau of American Ethnology, who saw oral traditions as an indicator of general processes of unilinear cultural evolution. For Boas, oral traditions reflected particular historical processes of each tribe in which they were told. Thus, by collecting a wide range of texts from many Northwest Coast communities, Boas attempted to address questions concerning the history of the distribution of Northwest Coast cultural groups. Some of his investigations along these lines have become useful contributions to an overall historical picture, while others have not stood the test of time. Two examples of his numerous observations will illustrate the point.

Boas successfully proposed that the Tsimshian embarked on a late migration into the area they now inhabit, arguing this point on the basis of the similarity of their myths to the myths of interior and southern North American Native peoples (Boas 1916:872). Though this movement occurred on a much longer time-scale than Boas had projected, his hypothesis has been further substantiated with linguistic and archaeological evidence (Sterritt et al. 1998:15-24).

Boas similarly proposed that the villagebased Coast Salish were recent migrants to the coast, having come originally from the interior and then influenced by their clan-based neighbors, the 
Kwakiutl (Boas 1898a:17-18). The hypothesis of a late Coast Salish migration to the coast has now been rejected by archaeological and linguistic evidence (Ames and Maschner 1999:86; Matson and Coupland 1995:242-6; Thompson 1979). Snyder concludes that for texts such as these it is difficult to know where these stories really originally came from, as so many narrative elements are widely shared throughout western North America (Snyder 1964:56-7), and thus rejects using myth as a marker of historical distributions of cultural groups.

Boas' second main theoretical position for understanding oral traditions drew on his position as a cultural relativist. By the time the Jesup Expedition had run its course, Boas had become more interested in trying to understand Native culture §્ on its own terms. For Boas, an observer from outI side the culture being studied would not necessarFily know the significance of what had been said ôtand done, or even what was significant and what . was not. To counter this problem, Boas worked ธิ่ with Native informants, who collected material in the language spoken by the community they were studying. He felt that these texts:

... probably contain all that is interesting to the narrators and that in this way a picture of their way of thinking and feeling will appear that renders their ideas as free from the bias of the European observer as possible. (Boas 1935:v)

This would be published in its entirety so that all significant material was present. Making complete d collections of Native oral traditions from a particular community provided a methodology to achieve fairly rich cultural descriptions. This perspective was developed in explicit opposition to the evolutionary ideology of his American counterparts, who viewed mythology as being "primitive rationalization," which survived as irrational custom. Boas then set out to use these texts as a basis for ethnographic observations on the culture of the peoples from whom the stories were taken.

In his work with Hunt and Tate, Boas felt he had a sufficient body of material to make authoritative statements on the cultures as wholes. Boas' two major analyses exploring this idea, Tsimshian Mythology (1916) and Kwakiutl Culture as Reflected in Mythology (1935), were lengthy projects that drew solely on mythology to state "ethnographic facts" about the culture of the societies from which the myths were recorded. These works read like long, detailed lists of cultural elements. They provide an annotated index to the myths on topics of material culture, personal and family life, tribal organization, emotional life and ethics, ceremonial objects and procedures, supernatural power and objects, numbers, the world, supernatural beings, animals and plants, and the origin of local geographic features. This range of topics covered was constructed inductively from the content of the myths themselves, and thus, according to Boas' theory, were the things important from the Native point of view, unbiased by the interests of the observer. The conclusions of these works return to his previous interests in the connections and differences between the groups on the Northwest Coast, connections which he believed could be seen from patterns of similarities and differences in the content of the myths.

Boas' peers critiqued him for not providing adequate context to interpret whether the myth contains borrowed events or themes and thus might represent non-local cultural practices (i.e., Barbeau 1917:551). This critique did not pose a problem for Boas, who saw each culture as being constituted by its unique historical development in interaction with neighboring groups. Thus, a borrowed element was just as important to the Native view as a local one, in a culture which at any given moment was the product of a dynamic history.

Boas also ran into trouble in his assertion that the oral traditions told or collected by his individual informants represented notions held by the culture as a whole. His final cross-cultural comparisons illustrate the difficulties inherent in this view. Boas concluded that there is a direct correlation between the number of occurrences of particular kinds of historical events mentioned in the myths, like starvation and natural disasters, and the actual relative frequency of those events in the history of the societies which the myths are believed to describe (Boas 1935:173). In making further distinctions between the interests of the cultures being described, Boas distinguished "the selection of preponderant themes, ... the style of plots, and . . . their literary development" (Boas 1916:878). The Kwakiutl, Boas lamented, are interested mainly in rank and privileges and are otherwise "lacking in variety of subject matter and in skill in composition" (Boas 1935:190). The Tsimshian, on the other hand, were said by Boas to be mainly interested in Raven's voraciousness, Mink's amorousness, and the marriage between humans and animals (Boas 1916:877). Since Tate did not provide stories of ownership, Boas concluded that they were missing from Tsimshian mythology (Boas 1935:176). Though Boas claimed 
that he had published all there was to collect of Kwakiutl and Tsimshian mythology, his critics strenuously disagreed, noting "almost endless are the stories" in complex cultures like these (Barbeau 1917:552).

All of these conclusions were based on the central notion that the oral traditions recalled or recorded by Hunt and Tate represented a complete body of narratives from their respective cultures. This is clearly a problematic position to take if one considers the possibility of personal agency. However, although Boas frequently published several versions of stories by different narrators, in his analyses he did not consider the relationship between individual style and variation in narrative form. Nor did he see oral traditions as being part of an active social context. For Boas, the content of the s్d.tories stood as the substance of what there wasto be analyzed, regardless of individual style or use of a story as a social tool. Thus, as ethnographiç্⿸厂⿱二⿺卜丿) of living communities, these works are disappointing.

ธิ่ If we reject Boas' practice of allowing the textg narrated almost exclusively by a single collabs్tator to stand for the society as a whole, we can of the Kwakiutl and Tsimshian. Berman points out that:ुin Boas' correspondence, he certainly asked for 范range of texts. His requests, however, were metawith silence from the collaborators who were eithfir unwilling (Hunt) or unable (Tate) to produce text from outside their relative social sphere (Beg్gnan 1991:45; Maud 1989:161). It seems clear thatơthese emphases in myth are a reflection of the

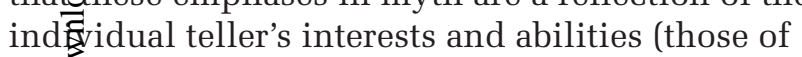
Hul and Tate), and cannot necessarily be extrapolated for application to whole societies. George Hunt, for instance, was a potlatching community member, very much worried about the same issues he recorded, and thus was apt to pay special attention to recording, for Boas, stories which were concerned with property (Berman 1991; Suttles 1991).

Tate's own narratives were guided firstly by his status in the community. Tate was not a highstanding community member like Hunt (Barbeau 1917:553), and likely did not have access to the range of stories recorded by Hunt. Viola Garfield, who worked with the Tsimshian in the 1930s and 1940s, confirmed this. She noted that Boas had presented the mythology "as if it were general community property. Only a few stories in Boas' published collections were identified as property or as explanations of historical details of lineages and clans" (Garfield 1966:52). Garfield saw that not a single Raven story told to her by Gitksan people bore any similarity to those collected by Tate from the Tsimshian (Garfield 1966:53). This demonstrates the highly limited range of stories Tate had access to, or that he was willing to tell, due to the proprietary nature of many Northwest Coast myths. Barbeau further observed that Tate had often simply restated Nisga'a stories that Boas had previously collected and published. Tate's restating the Nisga'a stories arose in part from a misunderstanding of Boas' instructions (Maud 1989:16).

More careful attention to the range of narratives from any particular ethno-literary category might have drawn Boas' attention to these problems. Seguin notes that Tate's texts "include few of the adaox [adaawk] and more of what might be called 'stories'... The Beynon texts [which were collected in collaboration with both Boas and his critic Barbeau] are much richer in the adaox but have figured little in the published literature" (Seguin 1985:24). Hunt, on the other hand, "consulted a wide range of Kwagul in producing these texts and the variability the texts display is probably a more accurate picture of the state of cosmological opinion in many societies than what anthropologists show us" (Berman 1991:132).

A more contemporary critique of Boas' project comes from Hymes, who has challenged the idea that the oral traditions told by individuals can stand as authoritative representatives of the traditions of the entire culture (Hymes 1996). Hymes has looked at different tellings of Coyote stories and has shown that very different meanings emerge from the various tellings of the same stories. This observation points to the real shortcomings of the analyses of Boas, who was so interested in the objective content of the stories that he virtually ignored the structure of particular tellings and the meanings that individual tellers may have intended. For Hymes, Boas' legacy of presenting oral traditions as disconnected from the social process of their telling has had an impact on more mainstream (nonacademic) publications of Native mythology. Hymes suggests that we would best honor the thought of Native storytellers "not by extravagant generalization, but by close attention to the detail of their narrative skill” (Hymes 1996: 131).

Though these observations suggest that there are serious problems with Boas' attempt to understand culture from the Native point of view, there are a number of important points that Boas makes that are useful today. The methodological implica- 
tions of Boas' program of collecting texts in Native languages in order to say something emic about Native culture, has become a very important idea in Americanist anthropology. Edward Sapir noted that these seemingly massive collections of texts are the minimum necessary for making a proper study of the language and culture of Native groups (Sapir 1912:194). The theoretical implications of Boas' methodology was the starting place for Sapir's vision of the relationship between language and culture (Darnell 1990), which in turn has had an impact on the development of the study of discourse in structural linguistics (Sherzer 1987), and anthropologists who study discursive practice as social action (Valentine and Darnell 1999:6).

Boas' work has laid the foundation for much future research on the Northwest Coast. No other \&્d researcher has shared his ambition to record and Fpublish so many oral traditions in their Native lanEuage, though many research projects have used ôthis material (largely the English translations) to pursue new theoretical problems. Before examinธิ่ ing the post-Boas work, Boas' unusual position in contemporary Native communities should be dis- cussed. Gloria Cranmer-Webster, great granddaughter of George Hunt and curator of the ¿ U'mista Cultural Center, has written about the im-

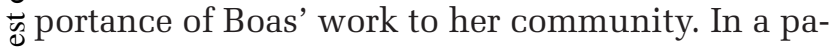
क् per detailing the contemporary significance of the ฉBoas material to her community, she mentions the İ importance of the Kwak'wala texts:

We are re-claiming what was lost during the 'dark years', as our old people say. . . The missionaries almost succeeded in their efforts to wipe out our language, so that we utilize the Boas/Hunt texts in developing language materials to teach Kwak'wala to both adults and children. (Cranmer-Webster 1997:6)

Though the process today is very different than in Boas' time, his contributions in recording oral traditions continue to be used by the descendants of the Native peoples with whom he worked.

\section{The Social Function of Northwest Coast Oral Traditions}

\section{British Functionalism after Boas}

In the decades after Boas and his colleagues had done their fieldwork, new questions arose concerning Northwest Coast oral traditions. The new generation of anthropologists were more keenly interested in looking at how oral traditions functioned in society. What were their functions as law, in ritual guidance, or as cosmological expla- nations? Oral traditions, like other institutions such as the potlatch, filled a social role that could be described in relation to the functioning of traditional Northwest Coast societies. Many of these functions were recognized due to the influence of Malinowski, who saw myth as a social charter which validated the cultural institutions and customs of a culture, providing a common bond of social solidarity (Malinowski [1926] 1948). Finnegan (1992:34) reviews this literature, noting that emphasis was placed on the stability and homogeneity of the systems of oral traditions, and little emphasis was placed on local meanings or individual creativity. All oral traditions with mythical qualities tended to be viewed as myth, and most other forms more or less ignored, as they had little relevance for gaining an understanding of social structure.

Boas largely dismissed this perspective and repeatedly argued that there was too much local variability to see oral traditions as forming a social system to explain cosmology. This view comes out forcefully in his condemning review of Locher's The Serpent in Kwakiutl Religion (Locher 1932). For Boas, Locher had badly misread Boas' own data on Kwakiutl mythology and religion in suggesting that Kwakiutl myths form a systematic, integrated social system (Boas [1933] 1940). Given Boas' commanding presence in American Anthropology in general and on the Northwest Coast in particular, very few people attempted to take this perspective while Boas was alive.

One exception to this was Boas' own reading of Bella Coola oral traditions, where Boas did posit a connection between the particular social organization of an individual society and the content of their myths (Boas 1935:173). This connection was evident for Boas in the seemingly conflicting traditions of the Bella Coola, where each village has its own tradition concerning the origin of the world. Boas' explained the great variation in narratives as a reflection of the conception of property in Bella Coola communities; each community owns a distinct myth of origin and accompanying it are unique rights and privileges over resource areas (Boas 1898b:48). Thus what seem on the surface to be conflicting cosmologies, are in fact an integrated set of traditions around property, each held privately by the property-owning social unit.

The other exception to this hesitation to challenge Boas comes from the work of T. F. McIlwraith, who also worked with the Bella Coola. McIlwraith corrected an observation of Boas', that the Bella Coola all shared a systematic account of 
the universe, noting that the systematic account was only shared by two families (McIlwraith 1948:25, 294). In fact, Boas had only worked with a single man for ten days (Maud 1982:88-9), reminding us again of the problems of making generalizations about whole cultures based on information from single individuals. Nonetheless, McIlwraith (who was trained in Cambridge) saw the mythology of the Bella Coola as having a social function in integrating attitudes towards animals and supernatural beings (McIlwraith 1948:30), and as an integrating force in their social organization, with "myths now accepted as facts, [and] hav[ing] had a great influence on the lives of the people. In fact the social structure of the tribe has tended to conform to the myths" (McIlwraith 1948:118). McIllwraith also viewed Bella Coola origin myths as giving authority to the rituals performed (McIlwrajth 1948:292). McIlwraith, as Maud (1982:139) poing out, sees oral tradition from the perspective of it actual use in society, presenting the material firmly from the stance of having been there and hea\&gd oral traditions in use. While it is difficult to argữ with McIlwraith's analysis on one level, his emphasis on cultural homogeneity still alludes to a se ways for a multiplicity of social purposes by different people at different times. For the time, howeves.s. McIlwraith's two-volume ethnography of the Bell通 Coola stands in stark contrast to Boas' work.

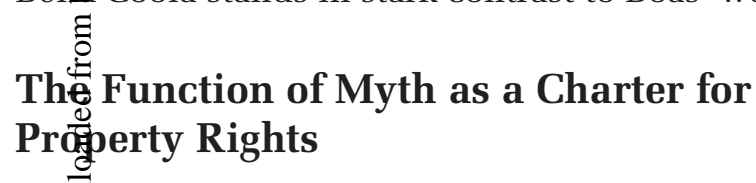

Thesstudents in American universities who were trai ed by Boas' students set about a project of publishing a fairly standard range of descriptive ethnographies, focusing on the memory culture of the older generation of Native people living in Northwest Coast communities in order to say something about traditional culture. These researchers generally worked only in English and were less concerned than Boas had been with collecting and publishing Native texts (i.e., Barnett 1955; Collins 1974; Drucker 1951; Duff 1952). They brought with them some of the critiques of the Boas school from British structural-functionalism, and set about to describe the operation of various social systems like the potlatch, winter ceremonials, and cosmology. The ethnographies were written in a fairly standard formula, and did not tend to include a section on mythology or oral traditions. Their Native informants, however, continued to bring up their stories during interviews with ethnographers. These oral traditions were integrated into the salvage ethnographies by being summarized for the purpose of a description of their role in Native explanations for social institutions or beliefs.

Nowhere was this more common than in descriptions of the social institutions of property and land tenure among Tsimshian and related communities on the northern Northwest Coast and in an exploration of Coast Salish cosmologies on the central Northwest Coast. These issues have continued to receive critical attention since the presentation of oral histories as evidence for land ownership and Native jurisdiction over the territory in the Delgamuukw case (Thom 2001). This section reviews some important publications from these areas, showing some of the commonalities and differences in approaches toward interpretation of oral traditions, and examining what the oral traditions themselves say about the cultures in which they originated.

\section{Myths and Property-Tsimshian, Gitk- san, and Nisga'a Adaaw $\underline{k}$}

Oral traditions for the Tsimshian, Gitksan, and Nisga'a (though certainly not a practice in only these communities on the Northwest Coast) have frequently been presented as being important in establishing hereditary rights and privileges. Though these oral traditions are almost always referred to as myths, the stories are more clearly from that intermediate class of myths and legends which is concerned with property rights, and which may be unique to the Northwest Coast (as discussed above). Three sources are useful to review in this regard, Viola Garfield's short but wellregarded ethnography of the Tsimshian (1966), Wilson Duff's publication of the oral traditions associated with the Tsimshian poles he collected for the British Columbia Provincial Museum (1959), and the recent presentation of Gitksan and Nisga'a oral traditions in support of a Gitksan land claim (Sterritt et al. 1998). ${ }^{4}$

When discussing Tsimshian myths, Garfield noted that the greatest number of texts concerned animals marrying humans in order to punish, instruct, and give power, crests, and gifts to them (Garfield 1966:49). She concluded that the motivation behind many of these myths is the deep interest of the Tsimshian in lineages, territories, and possessions (Garfield 1966:52). This relationship is evident when examining which individuals have knowledge of myths, as not everybody knows 
all the stories to the same degree, nor does everyone have rights to tell those that they may know. Raven-cycle myths, for example, are known by everybody. However, some particular episodes in the Raven cycle are family property, a fact which is publicly recognized on totem poles in front of the house of the owners.

Wilson Duff also discussed the relationship between pole owners, territories, and myths in his publication Histories, Territories, and Laws of the Kitwancool (1959). The Kitwancool, now called the Gitanyow, are a politically independent subgroup of the Gitksan. In the 1950s they reached an agreement with the British Columbia Provincial Museum to exchange their decaying totem poles for having their territories and laws recorded and mpublished. Duff asked a non-Native who had long \&ेtaught in the community and who spoke the lang guage of the Kitwancool to record the stories verbatim. He accompanied the stories with a short oेethnography that described the ownership of the stories and poles by individual house, each with a ธิ chief ranked according to the respect and authority he commands from others:

When a pole is erected or changed, it is erected at the same place. A feast is always given and the territories are discussed. They tell the people the size of their village, the mountains they own, their hunting and fishing grounds . . . they tell each clan which mountains they can have and what areas the can hunt and fish in. (Duff 1959:18)

Personal names and place names explicitly mentioned in the stories are the link of ownership between people and places. Thus, when chiefs tell myths, or rather have a hired speaker tell them at a potlatch feast, storytelling becomes an explicitly political act, authenticating claims to land and opening up the possibility of challenges from people with other stories.

The Gitanyow have made this argument again, using oral traditions, in a recent publication countering the overlapping land claim of their Nisga'a neighbors. Sterritt et al. (1998) have argued that in signing a treaty over a large territory, the Nisga'a have violated the indigenous law which recognizes the Gitanyow connection to some of those lands. This indigenous law, the authors argue, emerges from retelling the oral traditions that document land ownership (adaawk), marking household ownership of land on totem poles, and validating the land tenure at potlatch feasts.

Sterritt et al. (1998) claim that in Gitksan/Nisga'a law, the existence of an adaaw $\underline{k}$ proves ownership to the specific lands named in that story. Mentioning place names is critical in telling adaaw $\underline{k}$ to connect mythological elements of stories to specific, owned areas on the ground, which can be recognized today. Potlatch feasts are held to formalize the recognition of these ownership rights and to allow them to be contested. Thus, telling the adaawk and holding potlatches form an unambiguous system for asserting ownership of traditional lands.

In assessing their adaaw $\underline{k}$, the authors have done a remarkable job of working through a very large, diverse body of these stories, from old anthropological texts to court transcripts, to researchers' field-notes, pulling out concise statements about land ownership and boundaries. Where there appear to be inconsistencies in the various adaawk, the authors provide ample historical and ethnographic context to understand their place within the indigenous system of land tenure.

In interpreting these oral traditions, Sterritt et al. have given serious consideration to the foundations and content of aboriginal common law. The publishing of the adaaw $\underline{k}$ in a peer-reviewed academic press is in keeping with potlatch tradition that requires witnesses (readers) to claims being made and authorities (reviewers) to validate or challenge the claims. In reality, however, an academic publication is no potlatch. Unlike an oral recollection of an adaaw $\underline{k}$ at a potlatch feast, no one is able to stand up during the reading of a text and contradict what is being written.

Despite Boas' clearly mistaken claim that the Tsimshian were uninterested in property (Boas 1935), it is clear from these works that sorting out territories, boundaries, and property rights is one of the central functions of at least one type (adaawk) of Tsimshian oral tradition. This is not, however, the only interpretation of Tsimshian oral traditions since Boas did his work, as these and other myths also have been the subject of structural and post-structural analysis by Lévi-Strauss and others. There can be little doubt, however, of the importance of this functional reading of Tsimshian oral traditions in the context of contemporary land claims. Given that the land question is not settled in the rest of British Columbia, this kind of analysis has important implications for future research from this perspective.

\section{Coast Salish Cosmology, Power, and Property}

The dominant themes cited when describing and interpreting Coast Salish mythology in the post- 
Boasian ethnographies have been their importance in understanding cosmology and spirit power. Given the emphasis on inherited privileges and property in the Tsimshian (much of the other northern Northwest Coast) literature since Boas, this focus is striking. The difference in interpretive perspectives may partially be explained by the influence of the then-unresolved Boasian hypothesis that the Coast Salish were relative newcomers to the Coast and their property systems were a mere shadow of envy of those held by Boas' Kwakiutl. Anthropologists working in the salvage mode and interested primarily in traditional culture may not have been tuned in to or listening for concerns about property. However, given that recording of texts is supposed to alleviate ethnographers from the burdens of their interests, it does not seem like thiş्त̂would account for such a difference in ethnograthic emphasis.

Some of this difference may be accounted for by te particular historic situation of the timing of the field work. By the time trained anthropologists starofed to work in Coast Salish communities (the 1890ुs for the likes of Hill-Tout [1978] and Boas ${ }^{5}$, the 930 s to 1950s for Jenness, Barnett, Collins, and thergactively involved in making protests over the land question. They had been very active in the 187 Mc Benna-McBride commission hearings in the 191. maknng legal arguments about land title brought thes arguments to a temporary halt. This situation is ing contrast to the Tsimshian communities who wer actively engaged in protests continually thr@igh the early parts of this century (and indeed well into the end of it with the Calder and Delgamuukw cases and the Nisga'a Treaty) (Sterritt et al. 1998). The anti-potlatch lāws were also strictly enforced in Coast Salish communities, which were nearer the urban centers and the eyes of the law than their more northerly neighbors. In fact, it was in a Stó:lō (Coast Salish) community in Chilliwack that the first arrest and conviction under the antipotlatch law was made (LaViolette 1973:70). Thus it was seywen (spirit dancing), cosmology, and spirit power and not systems of property rights which caught the attention of this new generation of anthropologists interested in traditional culture. In spite of these particular interests of the postBoasian anthropologists working in Coast Salish communities, given the contemporary political context of unresolved land claims, it is important to see how Coast Salish communities may have framed oral traditions in terms of property, and how this is similar or different from the practices of other Northwest Coast groups like the Tsimshian.

Diamond Jenness produced two of the first post-Boasian ethnographies dealing with several Coast Salish communities, though one of these texts has languished as an unpublished typescript at the National Museum in Ottawa (now the Canadian Museum of Civilization) since 1934 (Jenness n.d., 1955). Jenness' unpublished manuscript reported on the Coast Salish communities of southeast Vancouver Island, where he had done several interviews with older men. His published account is the celebrated Faith of a Coast Salish Indian that is a verbatim reporting of a very long myth cycle told by the charismatic shaman Old Pierre (Jenness 1955). Jenness was always interested in collecting oral traditions, following the Boasian paradigm, as a means of understanding Native cosmologies. Like Boas, Jenness was struck by the highly variable responses to his questions to informants about their beliefs and cosmology (Jenness n.d.:105). By systematically describing the cosmological issues reported in the oral traditions he collected, however, Jenness was able to make several generalizations about how Coast Salish people understand their own existence, soul, thoughts, power, and relationship to animals (Jenness n.d.:108, 1955:35-37).

Jenness made some interesting observations about the connection between oral traditions and property. He noted that some rituals and associated stories were held privately, though it is unclear if he meant household, family, or village as the property-holding group (Jenness 1955:71). These private rituals and stories-collectively called $c \partial x^{w} t \varepsilon ' n$-include mask dances, powerful dolls, and stuffed animal rituals, supernatural fish, and funeral rituals. Jenness does not explicitly report these traditions as being linked to territory. However, the stories of the origins of many of specific ritual objects that may be used only by the family who owns the $c ̧ \partial x^{w} t \varepsilon^{\prime} n$ take place at specific, named locations to which those families have special association, including exclusive use of resources at these places. Additionally, in the long transformer-cycle myths recorded, the origins of particular communities are recounted, with named individuals establishing communities at named locations (Jenness 1955:10-34). Like the Tsimshian adaaw $\underline{k}$, both the personal and place names are recognizable in modern, post-mythological times. 
Homer Barnett, a student of Kroeber's, was the next person to do substantial ethnographic work in Coast Salish communities during the 1930s. His primary interests were in collecting lists of cultural traits and collecting data for very traditional descriptive ethnography. Working entirely in English, he made little effort to collect oral traditions. However, stories were an important medium for his informants. Tommy Paul, a Saanich from Vancouver Island, explained to Barnett about a violation taboo on telling the wrong stories (Barnett 1955:141). Stories are exclusive knowledge, particularly those about the original ancestors in the transformer-cycle myths. This exclusive knowledge (staalängan in Saanich, otakan in Comox) is "family owned and had to do with family history, myths and privileged acts."

One would not think of publicly claiming another's staalängan. He would be ridiculed unmercifully unless he could show a legitimate blood connection with its owners and could back up his claim with a property distribution. (Barnett 1955:141)

¿ิ This sounds very much like the $c ̧ \partial x^{w} t \varepsilon$ 'n described 하 by Old Pierre to Jenness.

In 1945, Helen Codere participated as a graduate student in an Columbia University ethno§ graphic field school in Stó:lō territory. Codere $\vec{\nabla}$ produced a number of locally important articles as $\mathrm{E}_{\mathrm{D}}$ a result of this project, one of which was a discuss'sion of the Coast Salish swai'xwe mask and associE ated origin myths (Codere 1948). The swai'xwe is a mask and regalia worn by a man who dances, havging been granted the privilege by a female or relative. ${ }^{6}$ Women whose families can claim the right to dance in this mask trace the privilege from specific stories that tell about the origin of the mask at a particular place, and how it is that the family came to possess it. After providing a full recollection of the myth from three different tellers and ample ethnographic details surrounding its importance in the community, Codere goes on to posit a very unsatisfying analysis (see Suttles 1957), claiming the myth and mask resulted from a mixing of more sophisticated northern Northwest Coast ideas of crests with the indigenous southern/central Northwest Coast ideas of spirit power. This is clearly a revival (or continuation) of Boas' theories of story-structure being a useful indicator of history, and the same criticism mentioned concerning Boas' analysis would apply here.

June Collins' research with the Upper Skagit (one of the Coast Salish peoples of Puget Sound) was ongoing from 1942 through to the 1970s. In an early article, Collins described the relationship be- tween humans and animals that Skagit oral traditions explain (Collins 1952). She outlines how respect for animals is expressed as a relationship of reciprocity. Taboos are outlined in oral traditions set in the time of the myth-world, and examples are provided for how to be courteous to animals. The origins of the first salmon ceremony is explained in these myths, and the philosophies behind the ritual practices of returning the bones of the first salmon to the river are described (Collins 1952:354). Like the ontological findings of Jenness, Collins discusses the relationship between the power of animals and humans to change form in myth and the actual experiences of contemporary Skagit individuals in their personal guardian spirit quest (Collins 1952:35). Another important ontological distinction is made visible in Collins' analysis of myth: the distinction between food and non-food animals. Animals that can be eaten as food are also competing with humans for access to food: whales eat seals, as do humans; bears eat berries, as do humans (Collins 1952:353). These are the animals that marry humans (Collins 1952:356), thus the production-reproduction metaphor in these myths, and the necessity for respect. Those that are not eaten as food (lizards, salamanders, etc.) are considered dangerous and are associated with shamanic powers in both myth and practice (Collins 1952:358).

After several decades of research, Collins published an ethnography of the Upper Skagit, where many of these ontological principles are restated (1974). Here she considers the function of myth as history, with history being divided into two periods-mythological and folkloric (Collins 1974:211). These historical periods are generally separated by the actions of the Transformer, who during the end of the myth-time set order, or natural laws in the world. Beyond using these stories to mark historical time, Collins recognizes the importance of myth for the relationships people have with their guardian spirits and with each other. Myths have moral content that is often quite explicit. Violations of the moral values described in myths have real world consequences. The victims of the violations will be protected by their guardian spirits. This concrete relationship between the telling of moral stories and the actual physical (spiritual) danger of breaking these moral values creates a cautious and circumspect social system of interactions between individuals (Collins 1974:214). This caution is extended from the unknown personal guardian spirits of other persons to the well- 
known, powerful spirits that live at particular places, which are also the subject of Upper Skagit myth and provide guidance for proper behavior at places away from the community (Collins 1974:241).

More recently, Collins has asked how people resolve for themselves the paradox of having a class-divided society that is essentially organized around kin units-where members of your own kin could occupy very different social statuses (Collins 1994). For Collins, this problem was resolved for the Coast Salish by borrowing traditions from the Kwakiutl, in accordance with the argument made at the time that this group had worked out a more complex system of social hierarchy than had their more simple southern neighbors. Here is Boas' pervasive argument again! However, the क्रroblem still remains, and may be better resolvd by looking at the meanings bound up in the oralinarratives themselves.

ठิSally Snyder developed this perspective of ora Ptraditions as a means of expressing unresolब्क्तिd conflict three decades earlier in her highly integesting but frequently overlooked Ph.D. dissertation (1964). ${ }^{7}$ In this comprehensive analysis of ove安100 narratives she collected in Skagit commurgities, Snyder moves back and forth between a pictzare of social organization constructed from ethr丽graphy to the content of myths and stories that oars on social organization. In the latter, she find social tensions abound (Snyder 1964:12). Inlaw are caught in the tension between privilege andgobligation. Women and older men are both pos My估s chart courses through these social tensions, giving the listeners (whom she calls "sophisticated") food for thought about the social tensions in their lives (Snyder 1964:59).

Like Jenness and Barnett, Snyder recognized myth as being a kind of private knowledge ["advice” $\left.x^{w} d i k w\right]$ owned by Coast Salish upper class families (1964:167-168, 210). Upper class genealogies are connected to oral traditions in the true stories told which outline the rights and privileges belonging to that family. The advice given concerning myths is not only the narrative of myth itself (which is important and also held privately), but advice concerning the interpretation of morals and proper (upper-class) behavior that are embedded in the myths. This concern with the private, proprietary nature of myths was in part responsible for her Skagit informants' concern to get the stories right. They said they would rather stay silent than to guess at meanings, or "pad, impro- vise, paraphrase or omit" the telling of a story (Snyder 1964:21).

Studies from this era of anthropological investigation of Coast Salish communities on the Northwest Coast successfully showed how these oral traditions serve an important function in expressing moral values and examples of how to (or how not to) have relationships with fellow community members (within and between genders and social classes) and with the spirit world. In the latter regard, these are not unlike myths told across North America. Of particular interest, though, is the role of Coast Salish myth as a discourse on property. Unlike the Tsimshian adaaw $\underline{k}$, the ethnographies of Coast Salish communities do not have a harmonious interpretation about the role of myth in the Native discourse of ownership of property. The nature of this system of property and the parallels to the Tsimshian adaawk need further clarification through further research in Coast Salish communities.

\section{Structuralism and the Search for Meaning in Northwest Coast Oral Traditions}

The massive corpus of texts made by the Boas-Tate (Boas 1912, 1916) and Barbeau-Beynon (Barbeau 1961; Barbeau and Beynon 1987) collaborations has provided the basis for several major forays into structural analysis. When Claude Lévi-Strauss cast his eye to the Northwest Coast, it was the mythology collected by Boas and his collaborators to which he would turn. John Cove's dense hermeneutic exploration of Tsimshian mythology (Cove 1987) was also based largely on these collections. These kinds of analyses use mythology as the core of their investigations, but unlike Boas, the investigators are less interested in Native ideas from the Native point of view.

Lévi-Strauss' widely read analysis of one of these myths, the Tsimshian "Story of Asdiwal" (Lévi-Strauss 1958, 1967) has been celebrated and debated (see Adams 1981:368-370 for a review). Lévi-Strauss' particular arguments about the structure of Northwest Coast mythology have been challenged from both an empirical perspective (i.e., Adams 1974) and from the perspective of the internal logic of his argument (Codère 1974; Thomas et al. 1976). Possibly the best summary of why LéviStrauss' structural approach to myth should be abandoned comes from Berman, who rejects

its inexplicable blindness to the importance of cultural provenience; its divorce of narrative form 
from the social, cultural and personal contexts in which that form is manifested; its preoccupation with discovering a single, simple universal type of narrative form; and finally its inability to demonstrate how analytical 'structure' or 'form' relates to the visual and aural 'texture' of actual oral-literary performances, to what is actually said and done in them. (Berman 1991:6)

Although the structural approach to the study of myth on the Northwest Coast has not been successful overall, there are some useful observations that can be made from examining the literature and some of the critiques. The debate provided an opportunity to bring into sharper focus some issues that had not been particularly well-articulated, specifically the skill with which some myths explore the consequences of broken social rules.

For Lévi-Strauss, this Tsimshian myth pro¿̊vides resolution and balance where the "contradictions" of cross-cousin marriages that Lóvi-Strauss identifies in the story are all resolved ố(Lévi-Strauss 1967:25). Unconcerned with original narrative form, or the quality of translation, Léviธิ Strauss identifies and defines four levels of symbolic opposition that, like music, operate on different levels of abstraction (Lévi-Strauss 1967:17-21). These opposites are not based on an o ethnographically informed reading of the myth, $\vec{s}$ nor on Native views about the meaning of their E⿱ own stories. Lévi-Strauss goes so far as to claim athat these levels cannot be separated by the Native I mind. According to Lévi-Strauss, these structural opposites serve the function of subconsciously reक्ष solving problems posed by actual contradictions in society (Lévi-Strauss 1967:28).

In critiquing the idea that the Tsimshian myth provides a symbolic balance, Adams says that Lévi-Strauss set up "a non-existent problem, found a solution to it (in a form of marriage) and then declared the solution inherently unstable, thus "proving" his assertion that normative rules only appear to resolve inherent contradictions" (Adams 1974:171). Adams, whose reading of Tsimshian myth is informed by his own extensive ethnographic research in the area, has an alternate reading: no two people who share rights to the same resources (i.e., who share kin ties) can marry each other. The only time that kin marriages can occur is when a person has been adopted into a different resource-owning group than the one into which they were born. For Adams, this myth is not about resolving subconscious contradictions, but rather plays the very familiar role of serving as a title or charter for resource-owning groups. Ultimately, Lévi-Strauss sees that the form of the myth and its meaning are linked, but his methodology for describing the form of myth draws on his own imagination and cultural constructions, rather than being attentive to Native literary style and culture.

John Cove (1987) has presented a more recent investigation of symbolic meaning in Tsimshian mythology. Cove looks at the Tsimshian myths recorded by Tate, Boas, Beynon, and Barbeau to build a model of the Tsimshian view of reality. Cove sorts out myths, which are common property (Cove 1987:46) from house narratives (adaawk), shamanic narratives, secret society narratives, legends, and folktales. He suggests that these commonly known myths contain a central, integrated message for the Tsimshian who tell them. Like the findings of both Jenness and Collins for the Coast Salish, the message is a kind of answer to the basic philosophical question of what it means to be human.

Cove looks at the symbolic significance of particular elements of myths-a stone, the salmon, skin-in order to get at these categories of humanness. The stone represents immortality and fixedness in this world. The salmon are immortal and can powerfully move back and forth between their world and the world of humans. Skin represents transformation between human and non-human forms. Cove reads meaning into these symbols by close exegesis of the content of the myths he has assembled, rather than in discussions with informants (who, when asked, were not able to give him the kinds of philosophical answers he was looking for) as Jenness and Barnett did, or by seeing how myths were used by people to make meaning in actual living situations.

The reading of Tsimshian mythology as being foundationally about the basic question that has also pre-occupied Western philosophy seems remarkable in light of the wide array of characters, themes, and incidents in the stories. Cove himself recognizes that only a single story, the very short and enigmatic Elderberry and Stone (see Kroeber 1986 for an enlightened discussion of the performances of this narrative), addresses directly this basic human dilemma. The symbolic meaning is not immediately obvious in the other stories. Rather, it must be investigated by a hermeneutic process of going back and forth between readings to see how the strands of symbolic significance connect from one story to the next, creating a deeper web of meaning than the one on the surface.

In drawing his hermeneutic circles, however, Cove underplays other interpretations of the very stories with which he is trying to come to terms. 
When his conclusion describes myth as being about one basic philosophical question, it places in the shadows the meanings that individual narrators and listeners might ascribe to the narrative. Such a symbolic study freezes meaning, or risks claiming that alternate readings of these stories are illegitimate. Cove's use of the authoritative thirdperson voice throughout the book reinforces this authoritative stance.

If one takes a different theoretical perspective and proposes that the ultimate meaning of oral traditions are completely contingent on the particular moment of the social context in which they are told, then such a hermeneutic analysis, as given by Cove, is unsatisfying. If, however, like Cove, one considers that meaning is held in the semiotic relations of the literary elements within the story, the stant on their own outside any particular use of therp in social practice. Of course, every time an oralôradition is heard (or read) it is in a social context of one kind or another, so taking such an extrerae view will lead to the problems such as those assĝfiated with Lévi-Strauss' interpretations. If, howyever, we take the post-structuralist (deconstruegetionist) view that meaning only exists at the morgent of practice, we neglect the important observation that language and discourses are structureal in ways so that meanings can be shared and understood by groups of people. Otherwise, commuffication would be impossible. Thus, we are led to the middle ground of trying to see the relationshiæbetween structure and agency, between semiotic delationships and the momentary performance of a communicative act. Cove does a better job thaß̨Lévi-Strauss of trying to understand agency, but could have spent more time sorting out the social contexts of recalling oral traditions to highlight the more nuanced ways in which meaning unfolds.

The differences between these two theoretical positions concerning symbolic meaning are clear when one looks at an analysis of Coast Salish mythology. Jay Miller and Lushootseed storyteller Vi Hilbert have published a short article describing the symbolic meaning of Lushootseed myths (Miller and Hilbert 1996). These myths describe the origin of contemporary villages, each of which has an ancestor who dropped from the sky. Aside from providing satisfying origin stories, Hilbert says myths teach you to live with your mistakes. Such a brief, almost obvious interpretation of Lushootseed stories by Hilbert in an academic publication defies the complex relationship she has with the power and meaning of the myths. Hilbert has worked with linguist Thom Hess and anthropologist Crisca Bierwert for many years, both translating texts and providing personal insight into their meanings and contexts (Bierwert et al. 1996; Bierwert 1999). The superficial explanation given in the academic publication is further illuminated by Hilbert's comments in her published collaboration with Bierwert et al.: "If I were to explain fully some incidents, I would disgrace myself. On these points, therefore, I . . . trust the intelligence of our audience to perceive the full significance of the event" (Hilbert, in Bierwert et al. 1996:4). Trusting the intelligence of the audience is a recurring theme in the presentation of Northwest Coast texts.

For Bierwert, the depth of meaning of Hilbert's Lushootseed stories becomes richer for the anthropologists who have made themselves familiar with the culture from which the stories emerge:

The depth and resonances of the stories are difficult to grasp at first because the narrations are thin in descriptive detail; they acquire depth on study and relistening and they are best at cuing a personally constructed image for someone who knows the culture. (Bierwert 1999:147)

The problem arises in building cultural knowledge through personal experience. Does this mean that the texts in and of themselves have no meaning? Of course not. Nevertheless, in ascribing meaning to a text taken out of its social setting there will necessarily be less social and cultural context. The context that does emerge is likely to be less socially potent for texts taken out-of-context than for texts that are analysed in active discourse. As a methodology, Bierwert suggests that if we can see something of the form and style of their original telling, at least some of the intended meaning of myths will be clear to the new listeners/readers (Bierwert 1999:154). From this, she concludes that the greater the listeners' knowledge of the rules of form and style, the greater their own understanding of the meaning. It is from a reading like this that we can move to more recent literary approaches to Northwest Coast oral traditions.

\section{Literary Approaches to Northwest Coast Oral Traditions}

Out of this century of academic discussions on Northwest Coast discourses emerges a fairly concise set of theoretical and methodological concerns. Paramount among these is a concern with 
cultural meaning. As Morantz has asked of oral histories generally, how can one presume to know the meaning of oral traditions when there is great social, temporal, cultural, and linguistic distance between teller and interpreter (Morantz 2001)? In many of the cases presented above, at least one of these interpretive barriers poses a central problem for an analysis of Northwest Coast myth. Since the important work of Dell Hymes in the early 1970s, several anthropologists and linguists working on the Northwest Coast have taken steps to address these problems. Some of these scholars have posited that oral narratives have been and continue to be an important part of Native cultural and political discourses. Also important is the renewed recognition that there is an important connection between language and culture, and that ¿े attention must be paid to this connection in the translation of oral traditions. The most important theoretical innovation, however, has been to recogonnize that the actual performances of oral traditions, where culturally and linguistically encoded ऽิ่ messages are transmitted, are critical to understanding their meanings.

\section{Translation}

о

When theoretical concerns turn to meaning, the ङ. problem of translation becomes a critical issue. a The translator is faced with the problem of not I only providing correct morphological equivalents for the words uttered, but also giving them shape I in a syntax which reads well in the new language. of This can be a problem where systems of syntax are very different. In Haida (like other Northwest Coast languages), phrases and sentences are centered on verbs, while in English they are centered on nouns. In making a smooth gloss translation into English, Bringhurst (1999) struggled with trying to evoke the motion and action being expressed in a verb-centered language. The English version given by Bringhurst is clearly different in both form and meaning than another translation that was not so attentive to the shape of the English language (i.e., Swanton 1905). The distinction between nouns and verbs is similarly ambiguous in Kwak'wala, making possible fine punning that is lost in translation unless extra context is given by the translator (Berman 1992:143). The translator has to consider the kinds of meanings the audience will read into the term when choosing a word for use in translation. Some terms may be best left untranslated, and explained in a footnote. Others may be translated using awkward or heavy phras- ing in English to give it the same kind of sense as the original term. In other situations the original sense may be simply lost or modified. Much, as the discussion of poetic form makes clear, depends on the audience.

In the fall of 1999 a flurry of controversy was reported in prominent newspapers and magazines in Canada over the publication of a book of "new translations" of Haida myths by critically acclaimed Canadian poet, Robert Bringhurst (Bringhurst 1999). ${ }^{8}$ This book, and the two others in its trilogy which followed (Bringhurst 2000, 2001), translated some of the Haida mythology collected by one of Boas' protégés, John Swanton. The issue that caught the mainstream media's attention was the relationship between Bringhurst, a non-Native scholar, and members of the Haida community, who argued that their myths are the property of particular Haida Houses that have exclusive rights to tell the stories. Bringhurst's highprofile publications and the controversy surrounding them raise a number of important issues. The books themselves are centrally concerned with the problem of translating oral traditions passed on by individual master storytellers across boundaries of time (over 100 years), medium (oral to written), languages (Haida to English), and, of course, culture. However, the main intended audience for Bringhurst's book is the non-Native, interested, sympathetic reader. The books are an excellent presentation of Haida history and oral narratives, and take into account many of the problems of presenting Native texts discussed here. Nevertheless, in excluding Haida people from the process Bringhurst has alienated one of his most important audiences.

Bierwert et al. (1996) have considered multiple audiences in their excellent presentation, translation, and contextualization of Lushootseed Texts. Here, the audience is taken to belong to three primary groups: 1) academic readers interested in Native oral literature in general and Salishan languages in particular; 2) Lushootseed community members interested in the stories or studying the Lushootseed language in a language program; and 3) a general audience of readers. To achieve a presentation that would appeal to all three audiences, the text was presented in a carefully transcribed, poetically organized Lushootseed form with a smooth English gloss (made at the sentence level ) on the facing page. Explanatory notes for culturally and linguistically particular features are left out of the translation of the text (not adding anything significant at the level of the 
sentence) but are provided in endnotes and in short contextualizing essays at the beginning of each story. Tapes are made available on request so that the stories can be heard as well as read. Significantly (and possibly uniquely), the copyright notice inside the cover of the book states: "The texts of the Lushootseed stories are understood to be part of Native cultural tradition and therefore no claim of copyright is here made upon them." This is a work that clearly acknowledges the community as both owner and potential audience of the stories. Unlike Bringhurst's Story as Sharp as a Knife, Lushootseed community members (particularly renowned storyteller Vi Hilbert) were intimately involved in producing the translations and explanations. In the recently published Lushootseed Dictionary (Bates et al. 1994), the editors havê made cross references to the occurrence of worels in these texts so that those who are looking to seie words in action may cross-reference back and 워아th between the Dictionary and Texts.

Several different schemes for presenting trarêflations have been tried, including 1) Englishonl $\sqrt{5}$ publication as translated by the editor; 2) Nativeftexts with technical morpheme-by-morpheme tran text:and smooth English gloss on facing pages; and 4) Eñglish-only publication as given by original tell解. Several problems in meaning should be considered. In the first method, the text given is furt flest from the original, with the most opportunitien for mis-communications to occur.

Dhe second approach is the most widely pra产iced; linguists are frequently the ones recording he texts. The morpheme analysis is an enormogs task and often leaves little opportunity for further consideration of the context social meanings in the stories. Such works are, however, the stuff of grammars and dictionaries and are vital academic productions. Tedlock (1983:31) has argued that the kinds of highly literal, morpheme-bymorpheme, phrase-by-phrase translations of Boas and his colleagues and students is for the most part "what professional translators would call a 'crib' or a 'trot'-not a true translation into literate English, but rather a running guide to the original text, written in an English that was decidedly awkward and foreign" (Tedlock 1983:31). The smooth English glosses produced in the second and third methods raise their own interesting problem. They are intended to give a close translation of the Native text. They do not represent the diction of Native speakers using English, but rather the invented English of the scholar working on the text.
This approach might best be done in collaboration with a poet and Native speaker to give the fullest and richest translation. Both Bringhurst (1999, 2000, and 2001) and Krauss (1982) have risen admirably to this task in their respective translations of Haida and Eyak oral traditions. The problem raised in the fourth method is a matter not of authenticity, but rather that of the possibility of losing devices and forms that are inherent in Native language and that give stories a unique meaning in their own context. It may be that a Native speaker is bilingual enough to reproduce these aspects in an English version, but this has not been explored on the Northwest Coast as it has been by Cruikshank (1999) in the Yukon. For her, documenting oral traditions in English by fluently bilingual storytellers creates more lively performed versions where the teller structures the translation on-thefly to make sure that their intended listeners hear what is being said.

Richard and Nora Dauenhauer have long been active in recording, translating, and publishing Tlingit oral narratives from the genres of life histories (Dauenhauer and Dauenhauer 1994), oratory (Dauenhauer and Dauenhauer 1990), and mythological oral narrative (Dauenhauer and Dauenhauer 1987). This work has formed an important body of accessible texts for students in Alaska wanting to learn and practice Tlingit. They typically present the Tlingit version, organized into verse form at the level of the phrase, and a smooth English gloss given on the facing page. Technical translations are left out of the printed texts, subverting the scholarly goal of linguistic analysis to the beauty and power of the Nativelanguage stories.

Extensive notes are included for each text to provide cultural and historical context, including extensive biographical information about the tellers and the event where the narratives were given and recorded. As a collection, these three large texts form a useful standard for language learning in a community that is already close to many of the cultural issues that the texts raise.

Richard Dauenhauer has published a number of scholarly analyses of Tlingit texts, some of which focus on the particular problems of translation. In an interesting, brief consideration of the problem of translating Native texts, Dauenhauer turns to two of the texts of mythological songs recorded in Tlingit by John Swanton during his fieldwork under the direction of Franz Boas (Dauenhauer 1981). Dauenhauer demonstrates the process of making careful translation at the level 
of both phrase and morpheme. He pays particular attention to the complex set of Tlingit kinship terms, which often have no English equivalents. He shows how in Swanton and Boas' translations into English and German there is a fundamental loss in

... everything functional and contextual-the
sense of what moved the singer to compose it, and
a sense of the song's impact on the Tlingit audi-
ence. Such deletions of kinship terms are the chief
cause of the anger and hostility knowledgeable
Tlingits universally experience and generally ex-
press when they see such translations in print...
From the Tlingit point-of-view, such versions are
not only un-Tlingit, but anti-Tlingit. (Dauenhauer
1981:362)

These comments reflect the importance of oral traditions to contemporary Native groups as part of ¿ेtheir identity. Getting the words right means not 产only being respectful during the field work Eprocess, but in on-going collaborative efforts with oे the community. Old-style anthropology, where translations of texts are made thousands of miles ¿ิ away with little subsequent involvement from Native speakers who are engaged in their communities, are no longer politically welcome, nor do they stand as useful academic translations. In addition oี to just being able to translate the language, it is $\overrightarrow{\mathrm{s}}$ clear that knowledge of linguistics and a poetic हonsense of English are both required to do justice to a totranslation of Native oral traditions.

Ethnopoetics and the Performance of Myth

Scholars working on the Northwest Coast in the generation after Boas had a keener interest in trying to describe oral traditions in ways other than the usual categories of song, narrative, poetry, or prose. Jacobs, for instance, suggested that oral traditions might best be presented as theater (Jacobs 1959b:7), rather than the straight prose presented in Boas' texts. Theatrical figuring of oral traditions would allow for more literary kinds of analysis that could highlight the relationships between character, plot, and theme. Jacobs trained a generation of scholars who worked on the Northwest Coast, making new recordings, transcriptions, and translations of these discourses (Seaburg and Amoss 2000:12-13).

The most well known of these students is Dell Hymes. Hymes has built on Jacobs' literary approach to Native oral traditions to lay the foundations for the school of the ethnography of speaking. Hymes is keenly interested in the importance of conventions of narrative form that generate meaning in oral traditions beyond the semantics of the words in the texts themselves. Hymes' analysis of Northwest Coast oral narratives has been worked mainly from Boas' texts, re-presenting them in verses, stanzas, and acts to reflect something of their narrative structure (Hymes 1981). In Hymes' own analysis of these old texts, the main statements he has been able to make about inferring meaning have been in recognizing patterned use of culturally important numbers (like 3, 4, or 5) in narrative rules (Hymes 1999:92). Scholars working in other indigenous communities such as Dennis Tedlock have tried to capture more of the performance aspects of oral narrative-like the particular evocative sounds and stresses in speech-in their transcriptions and translations, but these kinds of analyses have rarely been used on the Northwest Coast.

Linguist John Dunn, who has spent a career working on the Tsimshian language, regards oral narrative as a kind of literature that can be usefully studied using the techniques of poetic analysis. This is an analysis of a first contact narrative that is still owned by the house descending from one of the sisters of the main character in the narrative (Dunn 1989:396). Where this fairly typical Tsimshian oral narrative becomes literature is in the stichometric (lines and stanzas) and strophometric (aural performance features) structures. Lines can be identified in the story by the use of the Tsimshian marker "ada", (which is something like the English "then") which occurs with great frequency during the telling of the story. The stories' stanzas form quatrains, which is significant, as the Tsimshian culture number has been well established as being four. The strophometric features include regular pauses after the use of "then", dramatic length added to the syllables of some words and a regular pattern of cadences in the telling of the story. These performative features reveal an elaborate but regular set of parallelisms in the telling of this story and of stories of this class in general. However, beyond a detailed description of this structure and the recognition of the culture number pattern, Dunn draws little else from his analysis of this text as literature.

In contrast to Dunn's claim that Tsimshian narratives are a form of poetry, Halkomelem linguist Brent Galloway has made a careful examination of the narrative form of a Salishan Mink story to conclude that "there is no feeling of poetry here, but . . . artistry and tradition" (Galloway 1996:159). Rhymes and tight meters are what 
Galloway uses to distinguish a poem, but Halkomelem (and other Northwest Coast) narrative forms lack these features. Galloway describes several dominant narrative patterns (of discourse conjunctions, timing, and repetition) from the story, but concludes that "there is not necessarily one, and only one, correct structure that can be proposed" (Galloway 1996:167). This long, technical analysis by Galloway shows that even if very careful attention is paid to form (which in translation can help bring the story more authentically alive), a rigorous understanding of meaning may not ensue.

Poetic form has been attended to by other writers who do not concern themselves with trying to represent performance, as much as they want to represent something of the literary feeling of ođa narrative. Brian Swann (1985), for example, has e-presented narratives collected by Swanton as free-verse poetry. Swann's argument is that tho解h his work does not capture the literal or performance quality of the original oral traditions, he ్ffers an accessible representation for a Western judience. Such representations mask real differences between cultural concepts embedded in the

o Presentations like these shy away from the oftend difficult task of either trying to understand Nat the power-sharing that this requires) with someone wh\&does. The results of the collaboration between Bientwert, Hilbert, Hess, and Langen have masterfulg shown what can be done (Bierwert et al. 1996). The book includes both poetic and prose arrangements of the Native texts (depending on the gtyle of the oratory), drawing on performance features, an English translation which reveals Lushootseed poetic structures on the facing page, and extensive footnotes to provide linguistic and cultural annotations for the text given (Bierwert et al. 1996:24). The editors suggest that this kind of presentation can "carry their reader farther into the organization of thought and the art of the Lushootseed language and storytellers" (Bierwert et al. 1996:37) than more sparse translation projects might do.

In another effort to mediate this debate, Salishan linguist Anthony Mattina has also insisted that the "understanding which readers gain from the script is in direct proportion to what they know about the tradition and the context of the texts" (Mattina 1987:143). Thus the results of the laborious efforts to make poetic transcriptions that capture something of the form of the performance can be equally well achieved using prose transcription. The prose transcriptions Mattina provides are highly accessible, yet maintain an authentic relationship to the speakers of the oral narratives. The key to these accessible translations is his use of a close-to-literal translation, using the kinds of English words that would commonly be used by the Native speakers. This technique is useful for traditions that are living, which continue to be told and recorded, as in the Haida stories presented by Eastman and Edwards (1991), who also give a closer line-by-line translation in the appendix to their volume of stories.

\section{Form, Memory, and Meaning}

In an interesting analysis of form in Lushootseed stories, Langen recognizes a certain seeming paradox in the form of storytelling: the narratives often have very few words, but are highly repetitious. Langen asks us to think about how these two patterns of speech might interact with each other in the telling of Lushootseed narratives as a vehicle for information not declared (Langen 1989:80). Langen's first conclusion is that the very regular form of repetition in the oral narratives told by Lushootseed tellers likely serves as a mnemonic device for the complex set of incidences that are recounted in the long stories, that the storyteller "held the story in her mind as much by its shape as by its content" (Langen 1989:81). This mnemonic function is likely important, but still does not solve the problem of the paradox raised.

To understand how the laconic (but repetitive) telling of these stories can make sense to the listener, Langen compares them to the tellings done in English by storytellers who choose not to follow these narrative traditions so closely. Langen finds that in the stories that keep these narrative forms, the narrator uses a parallelism of actions and events to highlight the deeds of the main character. In the same story told by the other tellers without holding strictly to these narrative conventions, a short sermon is given at the end to capture the meaning of morals (Langen 1989:90). It would appear then, that such morals should become evident to those listeners who are attuned to the conventions of repetitive parallelisms. In a similar discussion, Langen critiques curriculum projects that have developed new tellings of Lushootseed stories and that emphasize (linear-thinking) rather than form (lateral-thinking) (Langen 1992). Langen suggests that Lushootseed storytellers working in their own language and in English use conven- 
tions of form to create richly embedded stories, but this is missed in following Western conventions of emphasizing linear developments in plot (Langen 1992:196).

Haida oral tradition also uses particular oratory devices to embed culturally-specific meanings (Boelsher 1991). Boelsher observed the operation of some of these practices in contemporary public discourse, which when practiced with cultural outsiders, poses a potential problem of crosscultural communication, where serious misunderstandings can occur from not recognizing narrative forms. She takes the example of political oratory where allusion, inversion, repetition, pausing, and silence are important rhetorical devices. These are typical of small-scale, face-to-face societies, where it becomes possible to say things without actually ¿्. articulating them. These ideas, which are only Ghinted at, would be lost on the outsider (BoelsherIgnace 1991:118-121). Thus when public oratory öcenters on land claims or fishing disputes, these . matters of sensitive literary translation have highly ธิ่ political consequences.

กิ

\section{Boas and Ethno-Poetics}

¿ These literary approaches to oral narrative have $\overrightarrow{\mathrm{s}}$ been discussed as providing a useful perspective on from which to approach oral traditions made in âclose collaboration between the storyteller and the I researcher. The texts produced are seen as being engaged in a highly active social context, where o meanings are negotiated between the tellers and of the audience, sometimes through the interpreting medium of the translator, who would ideally operate with an almost-invisible, highly poetic touch. So what can be made of older recordings of stories? Can it be that there is no meaning that can be brought out from the shelves of texts recorded by Boas and his colleagues? Or would an investigation of meaning in such texts be left to structural or symbolic analysts? There is one analysis which stands out as a highly successful attempt to draw on this literary perspective to investigate the problems of meaning in Boas' Kwakiutl texts, attending to the problems of the social context of the production of the texts, their social context as an ethno-literary category, the difficulties of negotiating both linguistically accurate and literate translation, and the connection between form and meaning in the texts. This is the excellent work of Judith Berman, who has drawn on these important insights into the analysis of oral narrative in a major re-evaluation of Boas' Kwakiutl texts (Berman
1991, 1992, 1994, 1996, 2000, 2001, in press).

Berman proposes that we must examine how the texts came to exist, how they were translated, and build an ethnographic understanding of the role of texts as social objects. Boas, she asserts, knew that getting texts in the Native language was important, but often made mistakes in his translations and more importantly said very little in the way of interpreting the patterns of performance (rhetorical) and genre form, which we now understand to be critical for interpreting meaning from stories (Berman 1992:126). In fact, in the case of the story "Oolachan-Woman's Robe," Boas could not have been more wrong in both his translation and interpretation of what Berman has shown to be a pun-filled, highly metaphorical, ribald story (Berman 1992).

In her Ph.D. dissertation, Berman sets out to investigate systematic relationships between the form and rules of oral literature, and the cosmological concepts and cultural meanings expressed in the stories published by Boas. The analysis is substantial. She begins by giving a biographical review of Boas' collaborator George Hunt and the historical and social context for how the volumes of "Kwakiutl Texts" were generated (Berman 1991:58-116; see also Berman 1994, 1996 which rework this section of her dissertation), and follows this with a robust description of nineteenth century Kwagul social organization, based on a linguistically informed reading of Hunt's work with Boas. Berman looks to the myths to say something about the relationship among tribe-villagehousehold-hearth to provide some new insight into the dynamic nature of these groups over time, to make commentary on social rank within and between groups, and to present the "chief" as a metaphor for the whole social body of the Kwagul.

From this ethnographic position, Berman works her way back to conducting an analysis of myth by discussing Kwagul ethno-literary categories, placing the nuyəm into context with other genres of Kwagul oral narrative (see Table 2). These "house-story" myths have few plot structures, but a great diversity of individual formation, being that they are "charters of social, political and personal identity ..." like a “. . . birth certificate or passport” (Berman 1991:128-9). This observation is important, as myths have often been taken to be "Durkheimian collective representations that transcend the opinions and understandings of any one individual" which can be interpreted as forming "a neat symbolic or conceptual system” (Berman 1991:132). For Berman, 
Table 2. Berman’s Partial Taxonomy of Kwagul Ethno-literary Categories (redrawn from Berman 1991:118).

\begin{tabular}{|c|c|c|c|c|}
\hline & \multicolumn{3}{|c|}{ пиуәт "myth, history" } & \multirow{2}{*}{$\begin{array}{c}\text { q'ayuł } \\
\text { "tale of recent } \\
\text { events" }\end{array}$} \\
\hline \multicolumn{3}{|c|}{ пиуәтił "house story" } & \multirow[t]{2}{*}{ [animal story] } & \\
\hline $\begin{array}{c}\text { nuyəmił } \\
\text { (short, public) }\end{array}$ & $\begin{array}{l}\text { nuyəmgiwi? } \\
\text { (long, secret) }\end{array}$ & $\begin{array}{c}\operatorname{lag}^{w} a ł \text { əm } \\
\text { [] "wailing song" }\end{array}$ & & \\
\hline
\end{tabular}

however, the patterned variability of the text provides a better picture of the cosmological opinions held by Kwagul society (Berman 1991:132). Thus having deconstructed static or largely structuralsyn雷olic interpretations of Boas' texts, Berman moves on to present a picture of what the patterns in narrative actually are, and how these may help in n⿳亠丷⿵冂丶

Berman examines one story closely, "Night Huझ्षैer and Day Hunter," starting with looking at the confext of how it was produced by Hunt and (mis-) tran̦s lated by Boas, then providing a re-translation, bas Kwa्gk'wala grammar, and organizing the new translation into ethno-poetic notation to reveal its form of versids, stanzas, scenes, and parts. She describes pattern勒 in 1) auxiliaries used, 2) performance form,

3) pfot-types, zones, and dramatis personae in nuy generally, 4) names and imagery used in performfance, 5) thematic aspects of characters in nuyă $m$ generally, 6) motifs in nuyəm generally, and fina然y, 7) the symbolic oppositions posed in the strugture of genre (and corresponding forms in real life). This part of her analysis takes up some 476 pages of double-spaced text, and is a careful, wellillustrated analysis.

At the end of the dissertation, Berman comes back to the first question-what can be understood from Boas' texts, or this text in particular. In response to Boas' unspoken theoretical concern with the problem of relativity, Berman suggests that Hunt's texts do, in fact, present what is important and meaningful to the Kwagul. Hunt himself participated in Kwagul winter ceremonial life both as a dancer and in initiating his son. What is important and meaningful is a basic concern with reversal and reciprocity, "in which relations between human and spirit, power and powerlessness, giving and taking" are expressed in a variety of imaginative ways by different presenters of the myths told (Berman 1991:712).
This is a very satisfying analysis and seems to get to the heart of the many of the methodological and theoretical issues raised. However, weighty re-analyses like these speak mostly to an academic audience. They lack a level of accessibility that would make them useful for people not schooled in this kind of analysis. Nevertheless, if the goal of this kind of work was to be accessible, the author would have to rely on the audience to bring the requisite knowledge to make an informed interpretation. Such an audience, presumably already fluent in the Native language, would likely not need to have these very basic principles about language and narrative form stated. The anthropological project is about producing stories about stories in a context other than the ones in which the original stories were presented. The anthropological project can be very good indeed at bridging the cultural and linguistic gap that might otherwise make these other discourses so difficult to understand, by attending to the problems of the social and political contexts of the stories, the manner in which they are translated as texts, and the relationship between form and meaning. As most of these efforts have, however, produced anthropology that is accessible to very few readers except for other anthropologists, we need to ask if the cultural divide is being adequately bridged. Clearly there is room for more accessible but rigorous discussion of Native discourses.

\section{Conclusions: The Past and Future of Oral Tradition Research on the Northwest Coast}

The anthropology of Northwest Coast oral traditions has been a long tradition, which has seen many changes in its theoretical goals and methods of analysis. The anthropology of Northwest Coast oral traditions has completed something of its own hermeneutic circle, starting with Boas' project of 
documenting Native texts in their own languages and his inductive analyses, which was countered by the British-influenced project of looking for the function of oral traditions in Northwest Coast societies. Lévi-Strauss moved the discourse to a discussion of meaning and symbolic structure, which was countered by a return to a Boasian attention to individual performances of oral traditions, but this time with a discussion of meaning through the interplay of narrative form and content. Though each approach has its own set of problems, the insights generated are worth summing up here, together with suggestions for future research.

Boas' efforts in transcribing texts in Native languages have provided an essential methodology for learning principles of Native grammars and to a certain degree, Native world views. Boas' monumental ¿े efforts, involving the publication of Native language texts, are obviously an important legacy now that many of these languages are endangered, moribund, ô or extinct. Continuing in the spirit of this tradition is of utmost importance if these languages are to surکิ่ vive a transition into a textual world.

ชิ The extraordinary volume of material left by Boas and his collaborators has been so influential in all of these studies that few are produced with¿ out at least reference to the original works, and of$\vec{s}$ ten using them as the central set of data for ङ્onalysis. Archaeologists and scientists with an insterest in natural history have continued to use Northwest Coast oral traditions in the spirit of Boas' early analyses, using them to aid archaeologo ical investigations and to understand geological ovents of the ancient past (i.e., MacDonald 1984; Marsden 2001; McMillan and Hutchinson 2002). However, given the continued problems of translation and the frequent difficulty of seeing the social context for the performance of these collections of narratives, scholars using this material can easily misinterpret the intent of the narrators and misunderstand the more general pattern of cultural meaning. Continuing work like Berman's and Hymes' re-translations of Boas' efforts into poetically sophisticated English is a worthwhile task. Translations of oral traditions work best when done collaboratively with researchers familiar with linguistic principles of Native languages (and a poetic sense of their own language) and in collaboration with fluently bilingual Native speakers. This kind of work must not eclipse the more important task of continuing to work with holders of these traditions, listening to how narratives are used in Native communities and providing new opportunities and venues-from the courtroom to the classroom-for narrators to use oral traditions as a way of expressing themselves. Cruikshank provides important guidance in working with oral traditions given in English, establishing the tellers themselves as their own best translators.

The other of Boas' major contributions was his attempt at grand comparisons of Northwest Coast oral traditions. Boas' Tsimshian Mythology stands unparalleled (though not without its critics, see Maud 2000) in seeing the patterns of motifs, episodes, and themes across Northwest Coast oral traditions (and again in larger contexts of North America and Siberia). Miller (1989) has drawn on Boas' analysis to make some general statements about the style and content of Northwest Coast mythology that can be held as some important defining elements of a vastly complex range of discourses. A few of these are worth repeating here. Concern with social ranking is shown through a mirroring of mythological worlds and human social statuses. Supernatural power is essential in acquiring food and prestige, with one of life's complexities involving the way in which that power is obtained, controlled, and maintained. To this list of elements, we can add Adams' summary of the contribution of structural studies of Northwest Coast myths, which hold that "in-law relations are important and that the relations between husband and wife are considered to be particularly, even mystically close" (1981:380).

Symbolic and structural accounts have been heavily criticized for moving too far from the intellectual lives of the people whose meanings they purport to uncover. This critique leaves open the question of how it is that researchers can try to make sense of the oral traditions that have been recorded over the last century. One way to move between flat historic narrations and translations of oral traditions and contemporary social contexts is by comparing the kinds of meanings the traditions have held over time. Harkin (1998) provides a recent exploration of the persistence of symbolic metaphorical meaning in Nuu-chah-nulth oral traditions. Harkin's analysis shows how overcoming the whale in traditional narratives is a highly potent and pervasive metaphor for the necessity for leaders to be "clean" in their own lives-overcoming their personal whales-in order to be respected by their communities. Harkin sees these oral narratives as important in Nuu-chah-nulth communities today, as leaders face new kinds of "whales" in their efforts in co-management and self-determination. This and other work by Harkin (1997) provides a refreshing approach to such narratives 
through his appreciation of the complexity of historic cultural patterns, and recognition of the ways in which oral traditions continue to hold power and meaning for contemporary community members. More work should be done to examine the contemporary social role of oral traditions and to see how these roles play against each other (i.e., in popular culture, contemporary politics, school curriculum). Studies like Boelsher's work with contemporary Haida political discursive practice (1988) are highly relevant in the current political milieu where Native culture is drawn on to make arguments for social justice and equality.

Finally, what have been the contributions of the studies of Northwest Coast oral traditions as literature? Clearly, such studies bring a careful and creative methodology to the processes of translationsand in the discovery of the relationships between narrative form and the range of meanings exp㢳 minst us of Boas' cautions in ascribing certain singular meanings to narratives, and move us towards an langelage and culture, tradition, and artistry. They alsônencourage anthropologists to engage in conversition with the people we study, to reflect on the fray our work is seen by others, and to appreciate that these stories and narratives have social live ${ }_{0}$ outside the scope of our academic discussion. If we read the end-pages of these books (i.e., Bierwert \&if al. 1996; Enrico 1995), they provide some morăl guidance on issues of cultural property righs and copyright, sometimes taking the indigenous social contexts of the stories being reported to heat, bringing them along with their messages and artigry into the textual world.

In this discussion of Northwest Coast oral traditions, individual stories have not been highlighted. This has been a critical study of an anthropological tradition and is less about a set of Northwest Coast narratives themselves. Having reflected on these treatments of Northwest Coast oral traditions, it is time to return again to the storiesthe Raven and the Transformer, the Boy who received his mask and spirit power from the lake, the Mouse who would not marry Beaver and Snake-and read, hear, or tell them with a new appreciation for how they can be meaningful and powerful in all their social lives to come.

\section{End Notes}

1. This review is limited to an examination of the "central" and "northern" Northwest Coast, omit- ting the literature for the "southern" region from the mouth of the Columbia River down into northern California. As the spellings of the names, and the relationships of one group to another is often difficult to follow on the Northwest Coast, a table of synonymy and standard groupings is provided in Table 1.

2. During his tenure as coordinator of the Jesup North Pacific Expedition, Boas directed his colleagues to also record texts-resulting in important volumes such as Swanton's Haida Texts (Swanton 1905, 1908) and the work of James Teit with the Nlakapamux (Thompson) (Boas [ed.] 1917; Teit 1898, 1912; see also Wickwire 1993, 1998, 2001) and less voluminous works such as Farrand's Quinault and Quileute texts (Farrand 1902; Farrand and Mayer 1919, respectively). While working at Columbia University, Boas inspired a number of students to collect and publish myths and oral traditions in areas he had not touched himself, including the important work of Edward Sapir with the Nuu-chah-nulth (Sapir 1924; Sapir and Swadish 1939), and some minor works in Coast Salish communities which he had not worked in himself (i.e., Andrade 1931; Gunther 1925; Haeberlin 1924).

In at least one of his early English-only publications, the editor of the journal Boas published in made complete deletions from the translation of the text, indicated by a string of asterisks, because of "certain expressions which are not suitable for publication” (Boas 1888:206).

3. Maud's critique of the Boas-Tate collaboration (Maud 2000) has, in turn, received some highly critical attention from anthropologists who are intimate with Boas and his work (Berman 2002; Darnell 2001; Raibmon 2001).

4. Relevant to the understanding of myths and property on the northern Northwest Coast is a large literature on the relationship between crest art (an important symbol for property and social organization) and oral tradition. Space does not permit reviewing all this literature in this paper, but the reader is directed to a number of excellent sources including: Barbeau 1950; de Laguna 1972; Garfield and Forrest 1948; and MacDonald 1983.

5. Published texts of oral traditions from Coastal Salishan languages include collections in Bella Coola (Boas 1895, 1898b, 1981, 2002), Island Comox (Boas 1888, 1981, 2002), Klahuse (Boas 2002), Sliammon (Boas 2002), the now extinct Pentlatch (Boas 2002; Kinkade 1992), Squamish (Boas 2002), Island Halkomelem (Boas 1889, 1981, 2002), Upriver and Downriver Halkomelem (Boas 1894, 2002), Straits Salish (Boas 1891, 1981, 2002), Tillamook (Boas 1898c), and a comparative 
analysis of Coast Salish Transformer stories (Boas 1916:586-610).

6. This has been of interest as one of the only matrilineal inheritance practices of the dominantly bilateral central and southern Northwest Coast peoples and stands in contrast to the more well known matrilineal property-holding groups of the northern Northwest Coast.

7. Unfortunately, only one short publication on her theoretical perspective and methodology for understanding oral tradition came out of the dissertation work (Snyder 1968) and another article on the potlatch (Snyder 1975), which has been reviewed very favorably (Adams 1981:376), but has received little subsequent attention. Snyder's work deserves closer attention in Northwest Coast studies, particularly her insights into the lives and soठ․ cial position of women.

.60․․ Anne Moon, Whose Culture Is It, Anyway?, Times Colonist (Victoria), June 20, 1999, p. 10; ठे Hugh Brody, Pilgrimage To the Poem: Using raw materials collected nearly a century ago, an acธิ complished Canadian storyteller takes a journey to

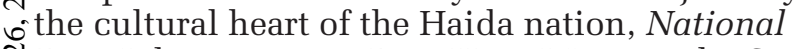
Post, July 6, 1999, p. B11; Hans Werner, The Soul of Haida Gwaii, The Toronto Star, July 11, 1999; $\approx$ Mark Abley, Haida Tales Brought Back to Life: B.C. poet translates record of oral verse made by an$\circlearrowleft$ thropologist The Gazette (Montreal), April 10, 1999, p. J4; Candace Fertile, Haida Mythology Echoes Inclusively, Calgary Herald, July 3, 1999, p. D7; Norbert Ruebsaat, Tricking the Trickster, Vancouver Sun, May 29, 1999, p. E11; The Myths and the White Man: experts on the stories of the Haida First Nation are infuriated by Vancouver poet Robert Bringhurst's new book, Globe $\&$ Mail, Nov 15, 1999, p. C3; John Bemrose, The Timely Wisdom of Traditional Tales: the penetrating beauty and great art of Haida poetry shines through in new translations by West Coast poet and linguist Robert Bringhurst, Maclean's, v.112(28) July 12, 1999 p. 56; Val Ross, Lost Masterpieces Regained Globe \& Mail, July 17, 1999 p. C8; Dorothy Bartoszewki, Land to Stand On, CBC Radio Ideas, June 20, 27, 2001.

Acknowledgements. The author would like to gratefully acknowledge a number of important sponsors of my work. First I would like to thank a number of agencies who have funded my doctoral dissertation research, during which this paper was prepared. The Social Sciences and Humanities Research Council of Canada provided a doctoral fellowship; Wenner-Gren Foundation provided a Doctoral Small Grants award; The Jacobs Fund provided a Research Grant; BC Heritage Trust provided a Graduate Studies scholarship. I would like to thank Toby Morantz for invaluable advice and guidance in preparing this paper, and to Susan Kaplan, editor of Arctic Anthropology, and the anonymous reviewer for their insightful suggestions.

\section{References Cited}

Adams, John

1974 Dialectics and Contingency in "The Story of Asdiwal": An Ethnographic Note. In The Unconscious in Culture: The Structuralism of Claude Lévi-Strauss in Perspective. Ino Rossi, ed. Pp. 170-178. New York: E. P. Dutton.

1981 Recent Ethnology of the Northwest Coast. Annual Review of Anthropology 10:361-392.

Ames, Kenneth and Herbert Maschner

1999 Peoples of the Northwest Coast: Their Archaeology and Prehistory. London: Thames and Hudson.

Andrade, Manuel

1931 Quileute Texts. New York: Columbia University Press.

Barbeau, Marius

1917 Review of Boas' "Tsimshian Mythology.” American Anthropologist 19(4):548-563.

1950 Totem Poles. 2 vols. Anthropological Series 30, Ottawa: National Museum of Canada Bulletin 119.

1961 Tsimsyan Myths. Anthropological Series 54, Ottawa: National Museum of Canada Bulletin no. 174 .

Barbeau, Marius and William Beynon

1987 Tsimshian Narratives 1: Tricksters, Shamans, and Heroes. John Cove and George MacDonald, eds. Canadian Museum of Civilization Mercury Series, Directorate Paper no. 3, Ottawa: Canadian Museum of Civilization.

Barnett, Homer

1955 The Coast Salish of British Columbia. Studies in Anthropology no. 4, Eugene: University of Oregon Press.

Bates, Dawn, Thom Hess, and Vi Hilbert

1994 Lushootseed Dictionary. Seattle: University of Washington Press.

Berman, Judith

1991 The Seals' Sleeping Cave: The Interpretation of Boas' Kwak'wala Texts. Ph.D. dissertation, Department of Anthropology, University of Pennsylvania.

1992 Oolachan-Woman’s Robe: Fish, Blankets, Masks, and Meaning in Boas's Kwak'wala Texts. In On the Translation of Native American Literatures. Brian Swann, ed. Pp. 125-162. Washington, D.C.: Smithsonian Institution Press. 
1994 George Hunt and the Kwak'wala Texts. Anthropological Linguistics 36(4):483-514.

1996 "The Culture as it Appears to the Indian Himself": Boas, George Hunt, and the Methods of Ethnography. In Volksgeist as Method and Ethic: Essays on Boasian Ethnography and the German Anthropological Tradition. George Stocking, ed. Pp. 215-256. Madison: University of Wisconsin Press.

2000 Red Salmon and Red Cedar Bark: Another Look at the Nineteenth-Century Kwakwaka Winter Ceremonial. BC Studies 125/126:53-98.

2001 Unpublished Materials of Franz Boas and George Hunt: A Record of 45 Years of Collaboration. In Gateways: Exploring the Legacy of the Jesup North Pacific Expedition, 1897-1902. Igor Krupnik and William Fitzhugh, eds. Pp. 181-213. Washington, D.C.: National Museum of Natural History, Smithsonian Institution.

Review of Transmission Difficulties: Franz Boas and Tsimshian Mythology, by Ralph Maud. American Ethnologist 29(3):775-777.

In $\overparen{\delta}$ "Some Mysterious Means of Fortune": A Look preș. at North Pacific Coast Oral History. In Coming to Shore: Northwest Coast Ethnology, Traditions, and Visions. Marie Mauzé, Michael Harkin, and Sergei Kan, eds. Lincoln: University of Nebraska Press.

\section{Bier节ert, Crisca (ed.)}

1996 Lushootseed Texts: An Introduction to Puget Salish Narrative Aesthetics. Lincoln: University of Nebraska Press.

Bier'्dert, Crisca

199 Brushed by Cedar, Living by the River: Coast Salish Figures of Power. Tuscon: University of Arizona Press.

Boas, Franz

1888 Myths and Legends of the Çatloltq of Vancouver Island. The American Antiquarian 10(4): 201-211; 366-373.

1889 Notes on the Snanaimuq. American Anthropologist 2:321-328.

1891 The Lku'ñgen, Second General Report on the Indians of British Columbia. Report of the Sixtieth Meeting of the British Association for the Advancement of Science, pp. 562-582.

1894 The Indian Tribes of the Lower Fraser River. Report of the Sixty-fourth Meeting of the British Association for the Advancement of Science, pp. 454-463.

1895 Salishan Texts. Proceedings of the American Philosophical Society 3:431-448.

1898a Traditions of the Tillamook Indians. Journal of American Folklore 11(40):23-38, 133-150. 1898b Introduction to James Teit "Traditions of the Thompson Indians of British Columbia." In Memoirs of the American Folklore Society no. 6. Franz Boas, ed. Pp. 1-18. New York: American Folklore Society.

1898c The Mythology of the Bella Coola Indians. Memoir of the American Museum of Natural History, vol. 1, The Jesup North Pacific Expedition. New York: American Museum of Natural History.

1903 The Jesup North Pacific Expedition. The American Museum Journal 3(5):69-119.

1910 Kwakiutl Tales. Columbia University Contributions to Anthropology no. 2. New York: Columbia University.

1912 Tsimshian Texts (New Series). Publications of the American Ethnological Society 3:65-285.

1916 Tsimshian Mythology. Based on Texts Recorded by Henry W. Tate. Pp. 29-1037. In Thirty-first Annual Report of the Bureau of American Ethnology for the Years 1909-1910, Washington, D.C.: Government Printing Office.

1917 Tales from the Lower Fraser River. In Folktales of Salishan and Sahaptin Tribes. Franz Boas, ed. Memoirs of the American Folk-Lore Society. 11:129-134, Lancaster: American FolkLore Society.

1935 Kwakiutl Culture as Reflected in Mythology. American Folklore Society, Memoir 28, New York.

1940 Review of "The Serpent in Kwakiutl Religion: A Study of Primitive Culture” by G. W. Locker. In Race, Language and Culture. Franz Boas, ed. Pp. 446-450. Chicago: University of Chicago Press.

1981 Indian Folktales from British Columbia. The Malahat Review 60:45-77.

2002 Indian Myths and Legends from the North Pacific Coast of America: A Translation of Franz Boas' 1895 edition of "Indianische Sagen von der Nord-Pacifischen Kúste Amerikas.” Randy Bouchard and Dorothy Kennedy, eds., Dietrich Bertz, trans. Vancouver: Talonbooks.

Boas, Franz and George Hunt

1905 Kwakiutl Texts. Memoirs of the American Museum of Natural History 5(1-3). New York.

1906 Kwakiutl Texts. Publications of the Jesup North Pacific Expedition 10(1). New York.

Boelscher, Marianne

1988 The Curtain Within: Haida Social and Mythical Discourse. Vancouver: University of British Columbia Press.

Boelscher-Ignace, Marianne

1991 Haida Public Discourse and its Social Context. The Canadian Journal of Native Studies 11(1): 113-135. 
Bringhurst, Robert

1999 A Story as Sharp as a Knife: The Classical Haida Mythtellers and Their World. Vancouver: Douglas and McIntyre, Ltd.

2000 Nine Visits to the Mythworld: Ghandl of the Qayahl Llaanas. Vancouver: Douglas and McIntyre Ltd.

2001 Being in Being: The Collected Works of Skaay of the Qquuna Qiighawaay. Vancouver: Douglas and McIntyre Ltd.

Codère, Hélène

1974 La Geste du Chien d'Asdiwal: The Story of Mac. American Anthropologist 76:42-47.

Codere, Helen

1948 The Swai'xwe Myth of the Middle Fraser River: The Integration of Two Northwest Coast Cultural Ideas. Journal of American Folklore 61(239): 1-18.

\&ิ Cole, Douglas

2001 The Greatest Thing Undertaken by Any Museum? Franz Boas, Morris Jesup, and the North Pacific Expedition. In Gateways: Exploring the Legacy of the Jesup North Pacific Expedition, 1897-1902. Igor Krupnik and William Fitzhugh, eds. Pp. 29-70. Washington, D.C.: National Museum of Natural History, Smithsonian Institution.

Collins, June

1952 The Mythological Basis for Attitudes towards

\% Animals Among Salish-Speaking Indians. Journal of American Folklore 65:353-359. Valley of the Spirits: The Upper Skagit Indians of Western Washington. Seattle: University of Washington Press.

1994 Kinship, Social Class, and Religion of Northwest Coast Peoples. In North American Indian Anthropology: Essays on Society and Culture. Raymond DeMallie and Alfonso Ortiz, eds. Pp. 82-107. Norman: University of Oklahoma Press.

Cove, John

1987 Shattered Images: Dialogues and Meditations on Tsimshian Narratives. Ottawa: Carleton University Press.

Cranmer-Webster, Gloria

1997 The Contemporary Potlatch. In Chiefly Feasts: The Enduring Kwakiutl Potlatch. Aldona Jonaitis, ed. Pp. 227-250. Seattle: University of Washington Press.

Cruikshank, Julie

1999 The Social Life of Texts: Editing on the Page and in Performance. In Talking on the Page: Editing Aboriginal Oral Texts. Laura Murray and Keren Rice, eds. Pp. 97-119. Toronto: University of Toronto Press.

Darnell, Regna

1990 Edward Sapir, Franz Boas, and the Americanist Text Tradition. Historiographica Linguistica 17:129-144.
Darnell, Regna

2001 Review Essay: Transmission Difficulties, by Ralph Maud and Potlatch at Gitsegukla, by Margaret Anderson and Marjorie Halpin. BC Studies 130:118-121.

Dauenhauer, Richard

1981 Notes on Swanton Numbers 80 and 81. Journal of American Folklore 94(373): 358-364.

Dauenhauer, Nora Marks and Richard Dauenhauer

1987 Haa Shuká, Our Ancestors: Tlingit Oral Narratives. Classics of Tlingit Oral Literature, vol. 1. Seattle: University of Washington Press.

1990 Haa Tuwunáagu Yís: For Healing Our Spirit, Tlingit Oratory. Seattle: University of Washington Press.

1994 Haa Kusteeyí: Our Culture, Tlingit Life Stories. Seattle: University of Washington Press.

de Laguna, Frederica

1972 Under Mount Saint Elias: The History and Culture of the Yakutat Tlingit. Washington, D.C.: Smithsonian Institution Press.

Drucker, Philip

1951 The Northern and Central Nootkan Tribes. Bureau of American Ethnology Bulletin, no. 144. Washington, D.C.

Duff, Wilson

1952 The Upper Stalo Indians of the Fraser Valley, British Columbia. Anthropology in British Columbia, Memoirs, no. 1. Victoria: British Columbia Provincial Museum.

1959 Histories, Territories, and Laws of the Kitwancool. Anthropology in British Columbia, Memoir 41-45. Victoria: British Columbia Provincial Museum.

Dunn, John

1989 Tsimshian Poetics. In General and Amerindian Ethnolinguistics: In Remembrance of Stanley Newman. Mary Keyand and Henry Hoenigswald, eds. Pp. 397-406. New York: Mouton de Gruyter.

Eastman, Carol and Elizabeth Edwards

1991 Gyaehingaay: Traditions, Tales, and Images of the Kaigani Haida. Seattle: University of Washington Press.

Enrico, John

1995 Skidegate Haida Myths and Histories. Skidegate: Queen Charlotte Islands Museum Press.

Farrand, Livingston

1902 Traditions of the Quinalut Indians. Memoir of the American Museum of Natural History no. 2. New York: American Museum of Natural History.

Farrand, Livingston and Theresa Mayer

1919 Quileute Tales. Journal of American Folklore 32(124): 251-279. 
Finnegan, Ruth

1992 Oral Traditions and the Verbal Arts: A Guide to Research Practices. London: Routledge.

Galloway, Brent

1996 An Upriver Halkomelem Mink Story: Ethnopoetics and Discourse Analysis. In Papers for the 31st International Conference on Salish and Neighboring Languages. Vancouver: ICSNL.

Garfield, Viola

1966 The Tsimshian and Their Neighbours. In The Tsimshian Indians and Their Arts. Viola Garfield and Paul Wingert, eds. Pp. 3-70. Seattle: University of Washington Press.

Garfield, Viola and Linn Forrest

1948 The Wolf and the Raven. Seattle: University of Washington Press.

Gunther, Erna

192尽 Klallam Folk Tales. University of Washington

N Publications in Anthropology 1(4): 113-170.

Haelzerlin, Herman

192 Mythology of Puget Sound. Journal of American Folklore 37:371-438.

in, Michael

1996. The Heiltsuks: Dialogues of Culture and History on the Northwest Coast. Lincoln: University of Nebraska Press.

199\& Whales, Chiefs, and Giants: An Exploration into Nuu-Chah-Nulth Political Thought. Ethnology 37(4): 317-332.

Hill:

197\% The Salish People (in four volumes). Ralph Maud, ed. Vancouver: Talonbooks.

Hill:

1999 The Meaning of Writing and Text in a Changing Americanist Tradition. In Theorizing the Americanist Tradition. Lisa Philips Valentine and Regna Darnell, eds. Pp. 181-194. Toronto: University of Toronto Press.

Hymes, Dell

1981 "In Vain I Tried to Tell You": Essays in Native American Ethnopoetics. Philadelphia: University of Pennsylvania Press.

1996 Coyote, the Thinking (Wo)man's Trickster. In Monsters, Tricksters, and Sacred Cows: Animal Tales and American Identities. James Arnold, ed. Pp. 108-137. Charlottesville: University Press of Virginia.

1999 Boas on the Threshold of Ethnopoetics. In Theorizing the Americanist Tradition. Lisa Philips Valentine and Regna Darnell, eds. Pp. 84-107. Toronto: University of Toronto Press.

Jacobs, Melville

1959a Folklore. In The Anthropology of Franz Boas. Walter Goldschmidt, ed. Pp. 119-138. Menasha: American Anthropological Association.
Jacobs, Melville

1959b The Content and Style of an Oral Literature. New York: Viking Fund Publications in Anthropology.

Jenness, Diamond

n.d. VII-G-9M, Box 39, F.1, Coast Salish Mythology. Canadian Museum of Civilization, Hull.

1955 Faith of a Coast Salish Indian. Memoirs in Anthropology no. 3. Victoria: British Columbia Provincial Museum.

Kinkade, M. Dale

1992 Translating Pentlatch. In On the Translation of Native American Literatures. Brian Swann, ed. Pp. 163-175. Washington, D.C.: Smithsonian Institution Press.

Krauss, Michael

1982 In Honor of Eyak: The Art of Anna Nelson Harry. Fairbanks: Alaska Native Language Center.

Kroeber, Karl

1986 Elderberry and Stone. Studies in American Indian Literature 10(1): 38-42.

Krupat, Arnold

1992 On the Translation of Native American Song and Story: A Theorized History. In On the Translation of Native American Literatures. Brian Swann, ed. Pp. 3-32. Washington, D.C.: Smithsonian Institution Press.

Lévi-Strauss, Claude

1958 La Geste d'Asdiwal. In Extrait de l'Annuaire, 1958-9, Ecole Prâtique des Hautes Etudes, pp. 2-43. Section des Sciences Religeuses. Paris: Ecole Prâtique des Hautes Etudes.

Lévi-Strauss, Claude

1967 The Story of Asdiwal. In The Structural Study of Myth and Totemism. Edmund Leach, ed. Pp. 1-47. A.S.A. Monograph 5. London: Tavistock.

Langen, Toby C. S.

1989 The Organization of Thought in Lushootseed (Puget Salish) Literature: Martha Lamont's "Mink and Changer." Melus 16(1): 77-93.

1992 Translating Form in Classical American Indian Literature. In On the Translation of Native American Literatures. Brian Swann, ed. Pp. 191-207. Washington, D.C.: Smithsonian Institution Press.

LaViolette, Forest

1973 The Struggle for Survival: Indian Cultures and the Protestant Ethic in British Columbia. Toronto: University of Toronto Press.

Locher, G. W.

1932 The Serpent in Kwakiutl Religion: A Study in Primitive Culture. Leiden: E. J. Brill.

MacDonald, George

1983 Haida Monumental Art: Villages of the Queen Charlotte Islands. Vancouver: University of British Columbia Press. 
MacDonald, George

1984 The Epic of Nekt: The Archaeology of Metaphor. In The Tsimshian: Images of the Past; Views for the Present. Margaret Seguin, ed. Pp. 65-81. Vancouver: University of British Columbia Press.

Malinowski, Bronislaw

1948 Myth in Primitive Psychology. In Magic, Science, and Religion and Other Essays.

Pp. 72-124. Boston: Beacon Press.

Marsden, Susan

2001 Defending the Mouth of the Skeena: Perspectives on Tsimshian Tliingit Relations. In Perspectives on Northern Northwest Coast Prehistory. Jerome Cybulski, ed. Pp. 61-106. Archaeological Survey of Canada, Mercury Series Paper no. 160. Hull: Canadian Museum of Civilization.

¿ิ Matson, R. G. and Gary Coupland

芘1995 The Prehistory of the Northwest Coast. New

空

Mattina, Anthony

1987 North American Indian Mythography: Editing

Cิ Texts for the Printed Page. In Recovering the

Word: Essays on Native American Literature.

Brian Swann and Arnold Krupat, eds.

Pp. 129-148. Berkeley: University of California Press.

Maud, Ralph

51982 A Guide to British Columbia Indian Myth and

อे Legend. Vancouver: Talonbooks.

1989 The Henry Tate-Franz Boas Collaboration on Tsimshian Mythology. American Ethnologist 16(1):158-162.

2000 Transmission Difficulties: Franz Boas and Tsimshian Mythology. Vancouver: Talonbooks.

McIlwraith, T. F.

1948 The Bella Coola Indians, in two volumes. Toronto: University of Toronto Press.

McMillan, Alan and Ian Hutchinson

2002 When the Mountain Dwarfs Danced: Aboriginal Traditions of Paleosceismic Events along the Cascadia Subduction Zone of Western North America. Ethnohistory 49(1): 41-68.

Miller, Jay

1989 An Overview of Northwest Coast Mythology. Northwest Anthropological Research Notes 23:125-141.

Miller, Jay and Vi Hilbert

1996 Lushootseed Animal People: Mediation and Transformation from Myth to History. In Monsters, Tricksters, and Sacred Cows: Animal Tales and American Indian Identities. James Arnold, ed. Pp. 138-156. Charlottesville: University of Virginia Press.
Morantz, Toby

2001 Plunder or Harmony? On Merging European and Native Views of Early Contact. In Decentring the Renaissance: New Essays on Early Modern Canada. Germaine Warkentin, ed. Pp. 48-67 Toronto: University of Toronto Press.

Raibmon, Paige

2001 Review of Transmission Difficulties: Franz Boas and Tsimshian Mythology, by Ralph Maud. Native Studies Review 14(1): 144-146.

Ridington, Robin

1999 Theorizing Coyote's Cannon: Sharing Stories with Thomas King. In Theorizing the Americanist Tradition. Lisa Philips Valentine and Regna Darnell, eds. Pp. 19-37. Toronto: University of Toronto Press.

Sapir, Edward

1912 Review Article. Kwakiutl Tales, by Franz Boas. Current Anthropological Literature 1:193-198.

1924 The Rival Whalers, a Nitinat Story (Nootka Texts with Translation and Grammatical Analysis). International Journal of American Linguistics 3(1):76-102.

Sapir, Edward and Morris Swadesh

1939 Nootka Texts: Tales and Ethnological Narratives, with Grammatical Notes and Lexical Material. Philadelphia: University of Pennsylvania, Linguistic Society of America.

Sarris, Greg

1993 Keeping Slug Woman Alive: A Holistic Approach to American Indian Texts. Berkeley: University of California Press.

Seaburg, William and Pamela Amoss

2000 Badger and Coyote Were Neighbors. Corvallis: Oregon State University Press.

Seguin, Margaret

1985 Interpretive Contexts for Traditional and Current Coast Tsimshian Feasts. National Museum of Man, Mercury Series, Ethnology Service Papers no. 98. Ottawa: National Museum of Man.

Sherzer, Joel

1987 A Discourse-Centered Approach to Language and Culture. American Anthropologist 89:295-309.

Snyder, Sally

1964 Skagit Society and its Existential Basis: An Ethnofolkloristic Reconstruction. Ph. D. dissertation, Department of Anthropology, University of Washington.

Snyder, Sally

1968 Stylistic Stratification in an Oral Tradition. Anthropologica 10(1): 235-259.

1975 Quest for the Sacred in Northern Puget Sound: An Interpretation of Potlatch. Ethnology 14(2):149-161. 
Sterritt, Neil, Susan Marsden, Robert Galois, Peter Grant, and Richard Overstall

1998 Tribal Boundaries in the Nass Watershed. Vancouver: University of British Columbia Press.

Suttles, Wayne

1957 The "Middle Fraser" and "Foothill" Cultures: A Criticism. Southwestern Journal of Anthropology 13:156-183.

1991 Streams of Property, Armor of Wealth: The Traditional Kwakiutl Potlatch. In Chiefly Feasts: The Enduring Kwakiutl Potlatch. Aldona Jonaitis, ed. Pp. 71-134. Vancouver: Douglas and McIntyre Press.

Swann, Brian

1985 Song of the Sky: Versions of Native American Songs and Poems. Ashuelot: Four Zoas Night House Press.

Sw角ton, John

190气 Haida Texts and Myths, Skidegate Dialect. Bureau of American Ethnology Bulletin no. 29. Washington.

1908. Haida Texts, Masset Dialect. Memoirs of the

तี American Museum of Natural History 14(2).

กิ New York.

Ted ڤึ̆ck, Dennis

198震 The Spoken Word and the Work of Interpreta-

tion. Philadelphia: University of Pennsylvania

ö Press.

Teit, हु.James

1898 Traditions of the Thompson River Indians of

E British Columbia. Memoirs of the American

О. Folklore Society 11:61-137.

191弯 Mythology of the Thompson Indians. Franz Boas, ed. Memoirs of the American Museum of Natural History 12, Publications of the Jesup North Pacific Expedition 8(2). New York.
Tennant, Paul

1990 Aboriginal Peoples and Politics: The Indian Land Question in British Columbia, 1849-1989. Vancouver: University of British Columbia Press.

Thom, Brian

2001 Aboriginal Rights and Title in Canada after Delgamuukw: Part One. Oral Traditions and Anthropological Evidence in the Courtroom. Native Studies Review 14(1): 1-26.

Thomas, L. L., J. Z. Kronenfeld, and D. B. Kronenfeld 1976 Asdiwal Crumbles: A Critique of Lévi-Straussian Myth Analysis. American Ethnologist 3(1):147-174.

Thompson, Laurence

1979 Salishan and the Northwest. In The Languages of Native North America: Historical and Comparative Assessment. Lyle Campbell and Marianne Mithnun, eds. Pp. 692-765. Austin: University of Texas Press.

Valentine, Lisa Philips and Regna Darnell (eds.)

1999 Introductions: Timely Conversations. In Theorizing the Americanist Tradition, pp. 3-18. Toronto: University of Toronto Press.

Wickwire, Wendy

1993 Women in Ethnography: The Research of James A. Teit. Ethnohistory 40(4): 539-562.

1998 "We Shall Drink from the Stream and So Shall You": James A. Teit and Native Resistance in British Columbia, 1908-22. Canadian Historical Review 79(2): 199-236.

2001 “The Grizzly Gave Them the Song”: James Teit and Franz Boas Interpret Twin Ritual in Aboriginal British Columbia, 1897-1920. American Indian Quarterly 25(3): 431-452. 